\title{
Legal Migration in the Relationship between the European Union and ACP Countries: The Absence of a True Global Approach Continues
}

\author{
Purdey Devisscher \\ Assistant, European Law Department, University of Ghent, Belgium
}

\begin{abstract}
For a long time, the relationship between the European Union (EU) and the African, Caribbean and Pacific Group of States (ACP) was characterized by the focus on trade issues. In recent years however, other policy aspects have emerged, amongst which migration. This evolution results from the gradual recognition of the importance of migration in the Union's external relations. The mainstreaming of migration in the relations with third countries raised the need for a Global Approach to Migration (2005) connecting illegal and legal migration, as well as introducing a positive migration-development nexus. The acknowledgement of a possible positive contribution of legal migration - if well managed - for developing countries, has resulted into new concrete initiatives such as circular migration, mobility partnerships and the Blue Card Directive. A closer look at the policy frameworks, as well as specific measures demonstrate however, that a true comprehensive approach is a long way from home. It is examined if the specific EU-ACP relationship offers a different point of view and effectively makes migration work for the development of both parties. More specifically, do the Economic Partnership Agreements (EPAs) correspond to the abovementioned goal? A comprehensive and coherent legal framework that unites the interests of the Union and its Member States, on the one hand, and those of the developing countries, on the other hand, seems a distant perspective. It is concluded that ambitious policy objectives have been set and are waiting to be addressed by corresponding policy frameworks and legal commitments.
\end{abstract}

\section{Keywords}

legal migration; comprehensive approach; developing countries; ACP; EPA

\section{Introduction: Uniting Conflicting Interests and Defining Concepts}

In recent years, migration has slowly developed as a headline on the international agenda and has been recognized as one of the strategic priorities of the Union and its Member States. Initially, this was approached as an internal issue, but it soon became clear that migration had to be integrated in the Union's external policy. The external dimension of migration was however essentially guided by security concerns ${ }^{1}$ and a "zero" immigration policy. ${ }^{2}$ In a globalizing and changing world

\footnotetext{
1) Security concerns are interpreted sensu lato, that is encompassing not only clear external threats such as terrorism, but also illegal migration issues, human trafficking, readmission etc.

2) Communication on "A Community Immigration Policy", 22.11.2000, COM(2000)757.
} 
this turned out to be unsustainable. The idea of a 'fortress Europe' and restrained migration had shown its limits. Gradually, the idea that well managed migration could serve both the Union and its Member States, on the one hand, and the developing countries, on the other hand, became prevalent. The former are more and more in search of highly skilled professionals as an answer to the demographic changes and in the attainment of the 2000 Lisbon Strategy and Europe 2020. The latter searching for a better and quicker attainment of the set development goals through optimizing legal channels for lower and unskilled migrants and limiting the negative effects of brain drain. The challenge was therefore to find a coherent, comprehensive and balanced policy and legal answers uniting both interests.

The category of legal migrants can be divided into two subcategories, more specifically economic migrants and asylum seekers and refugees. The first differs from the latter in the sense that economic migrants are not covered under international rules of protection for admission. There is no obligation under international law for states to let economic migrants enter their territory. In theory, an additional division could be made between voluntary and forced migration, but in practice there is a fine line between these categories. ${ }^{3}$ Economic migration is just as well inclined to be motivated by compelling push factors. Legal economic migration can benefit development in many ways, such as by tackling the root causes of migration as a long term development goal and through remittances. In the following analysis migration is addressed form the angle of the possible positive and negative effects of legal economic migration, hence from the stance of skills transfers or losses. The search for a common comprehensive approach from a human resource point of view is thus the underlying point of departure.

\section{A Legal Basis and a Policy Framework for Economic Migration to the Benefit of All?}

The Union's competence in migration is the reflection of the lack of political will and the reluctance of the Member States in conferring powers regarding legal economic migration to the Union and thus being clear constraints in the Union's capacity to formulate a common migration policy. The same trend can be identified in the numerous policy documents that shape the marked evolution in migration policy. The securitized vision on the external dimension of immigration progressed into a comprehensive approach encompassing illegal migration, ${ }^{4}$ legal

\footnotetext{
3) S.E. Findley, "Compelled to Move: the Rise of Forced Migration in Sub-Saharan Africa", in M.A.B. Siddique (ed.), International migration into the 21st century: essays in honour of Reginald Appleyard, Cheltenham: Elgar 2001, pp. 275-305.

4) Some prefer the term irregular immigration, since "illegal" migration has the negative connotation of criminal behaviour. E.g., Opinion of the Committee of the Regions on "A global approach to migration:
} 
migration and a migration-development nexus. The latter being at first limited mainly to the root causes of migration, thus the negative migration-development migration nexus. Slowly, the possible benefits of legal migration for development, corresponding to a positive migration-development nexus, gained ground. Together with this evolution, the need for more coherence between the different policies emerged, as did the call for an actual comprehensive approach and implementation of made political commitments.

\subsection{Constraints on the Union's Competence}

The Maastricht Treaty provisions on migration were to be found under the former intergovernmental pillar of Title VI concerning cooperation in the fields of justice and home affairs (Article K.1, paragraph 3 TEU). The Treaty of Amsterdam, integrating the Schengen acquis, transferred the powers on visas, asylum, immigration and other policies related to free movement of persons to the Community pillar (Title IVTEC). The provision on legal economic migration was to be found in ex Article 63, paragraph 3(a) TEC. This Article was kept in the Nice Treaty. Several provisions in the former TEC demonstrate the reluctance of Member States in transferring powers concerning economic immigration for third country nationals to the Community. The provisions of ex Article 63, paragraph 3 and 4 TEC were excluded from the obligation to take measures within a period of five years after the entry into force of the Amsterdam Treaty. Moreover, the provided possibility (Article 67 TEC), for the Council, after this five year transitional period to decide 5 to submit the adoption of measures under these provisions to the procedure of Article ex 251 TEC, which means qualified majority voting $(\mathrm{QMV})$ and co-decision, was never taken for measures concerning legal migration. ${ }^{6}$ Unanimity and consultation of the European Parliament (EP) remained the rule for the adoption of such measures. Regardless of the fact that no explicit provision on the Member States' competence regarding the volumes of admission of third country nationals coming from third countries in order to seek work, be it employed or self-employed, was present, the Union always recognized the limits of its competence in the area of legal economic migration. ${ }^{7}$ The current Lisbon Treaty is a copy of the failed Constitutional Treaty (resp. Article III-257

developing a European policy on labour immigration in conjunction with relations with third countries", OJ C 257/20 of 9 October 2008, point 14.

5) 2004/927/EC: Council decision of 22 December 2004 providing for certain areas covered by Title IV of Part Three of the Treaty Establishing the European Community to be governed by the procedure laid down in Article 251 of the Treaty, OJ L 396/45 of 31 December 2004.

6) S. Peers, "Key Legislative Developments on Migration in the European Union", European Journal of Migration and Law, Issue 9 (2007), pp. (229) 231 (251); S. Peers, "Legislative Update: EU Immigration and Asylum Competence and Decision-Making in the Treaty of Lisbon", European Journal of Migration and Law, Issue 10 (2008), pp. (219) 220 (247).

7) This appears for example from the Hague Programme (Presidency Conclusions, Brussels European Council, 4 and 5 November 2004, p. 19). 
and Article III-267). The objective to develop a common immigration policy was consolidated in Article 67, paragraph 2 TFEU and the specific aims of the immigration policy were inserted (Article 79 TFEU). Measures in the area of economic migration are now taken under the ordinary legislative procedure, co-decision and QMV (Article 79, paragraph 2(a) TFEU). The paragraph in ex Article 63 TEC allowing Member States to maintain or introduce in the areas (3 and 4) national provisions which are compatible with this Treaty and with international agreements, was removed. The specific provisions were completed with the explicit reference in Article 4 (j) TFEU that, for the external dimension, competence is shared in the area of freedom, security and justice. This seems to imply a concurrent shared competence, in the sense that Member States can exercise their competence as long as and to the extent the Union has not. The current treaty does not explicitly attribute more power to the Union, but it does clarify that there is a Union competence concerning economic migration, however with clear restrictions. ${ }^{8}$ Integration measures (Article 79, paragraph 4 TFEU) - possibly combined with incentives and support measures of the Union - and the competence to fix the number of immigrants coming from a third country in search for work (Article 79, paragraph 5 TFEU) remain Member State competences. The inclusion of the goal to develop a common immigration policy and specific objectives in Article 79, paragraph 1 TFEU might provide grounds for more intensive EU action, however taking into account the stated limitations. ${ }^{9}$

This evolution shows that economic migration remains a key element of the Member States' sovereignty. Nonetheless, the changed context demanded for a different and therefore a common European approach to migration, hence the abovementioned changes. The most important changes after the Amsterdam Treaty were the consolidation of the objective to create a common immigration policy and the shift in the decision-making procedure. Despite this step forward, it is clear that Member States have been and still are reluctant to transfer all of their powers regarding legal economic immigration. This often constitutes problems, but is not necessarily a plea to confer all remaining competence to the Union. First and foremost it is a question of coordination and coherence between the Member States and in relation to other policy areas.

A further distinction must indeed be made between EU's powers on legal economic migration and art. 207 TFEU, the common commercial policy (CCP), being exclusive, uniform and with no opt-outs. Nonetheless, trade in services might also result in the movement of persons. No matter this distinction, one will always influence the other. The provisions included in the agreements concerning

8) For further elaboration on the issue of competence concerning legal migration, see: S. Peers, "Legislative Update: EU Immigration and Asylum Competence and Decision-Making in the Treaty of Lisbon", European Journal of Migration and Law, Issue 10 (2008), pp. 219-247.

9) Peers, supra note 8, pp. (219) 239 (247). 
liberalization of services ${ }^{10}$ will determine the possibility to 'migrate' on a legal basis from the third country to a EU Member State to temporary perform an economic activity, but the provisions regarding an eventual long term residence status or visa issues remain in the immigration policy realm. This link is illustrated e.g. in the communication on a community immigration policy, ${ }^{11}$ where the admission for economic migrants is clearly linked to the respect of provisions in bilateral and multilateral agreements already in force, with a specific reference to the scheduled commitments under the General Agreement on Trade in Services (GATS). The connection between migration and trade in services is further recognized in a number of subsequent communications. ${ }^{12}$ In the following analysis it will be established that legal economic migration and the migrationdevelopment nexus is often a combination of both (infra, section 4).

\subsection{In Search of the Right Policy Framework}

The relevance of migration, and especially in connection to development and in relations with third countries has, for a long time, not been topping the agenda. The emergence of the external dimension of migration eventually led to the creation of a High Level Working Group on Asylum and Immigration (HLWG), however there was no question of cooperation with the identified third countries. ${ }^{13}$ It was only since the creation of the area of freedom, security and justice following the Amsterdam Treaty and the Tampere Programme ${ }^{14}$ that the first steps towards a common comprehensive approach on migration were taken. It was recognized that this could only be reached in partnership, dialogue and cooperation with third countries. This cooperation was however still regarded from a security point of view, limited in content and without clear priority objectives. ${ }^{15}$ It was only in the following years that the idea of possible benefits of migration for development (the positive migration-development nexus) through legal economic migration, whilst mitigating the negative effects of brain drain, was gradually integrated in the relation with third countries. ${ }^{16}$ Suggestions to reach both

10) Under the old provision of Article 133 TEC a concurrent shared competence and under the current art. 207 TFEU an exclusive competence.

11) $\operatorname{COM}(2000) 757$.

12) For example: Communication on "Migration and Development: some concrete orientations", 01.09.2005, COM(2005)390, p. 26; Communication "On Circular Migration and Mobility Partnerships between the European Union and third countries", 16.05.2007, COM(2007)248, p. 5 and p. 17.

13) J. Niessen, "International Migration on the EU Foreign Policy Agenda", European Journal of Migration and Law, Issue 4 (1999), pp. 483-496.

14) Presidency Conclusions, Tampere European Council, 15 and 16 October 1999.

15) M-H Chou, European Union Migration Strategy towards West-Africa: the Origin and Outlook of 'Mobility Partnerships' with Cape Verde and Senegal, 23-25 April 2009, 8 (26).

16) Presidency Conclusions, Santa Maria Da Feira European Council, 19 and 20 June 2000; COM(2000)757; Communication on "Integrating Migration Issues in the European Union's relations with Third Countries”, 03.12.2002, COM(2002)703. 
objectives were e.g., temporary migration and return and the creation of a European Code of Conduct addressing recruitment of health professionals in developing countries. The emergence for a more comprehensive approach was characterized from the start by a focus on the African continent, in particular Sub-Saharan Africa, as a priority area. Nonetheless, illegal migration and the limited attention for the positive development aspects of migration were still the main features. ${ }^{17}$

The new trend was endorsed in the Hague Programme, ${ }^{18}$ where the absence of a genuine fully fledged external policy and a coherent comprehensive approach linking migration, development cooperation and humanitarian aid was acknowledged. The first request to the Commission to draft a strategy on all the external aspects of the area of freedom, security and justice resulted mainly in a focus on illegal immigration, with only little reference to the ACP. ${ }^{19}$ This changed only later ${ }^{20}$ and finally found its reflection in the Global Approach. ${ }^{21}$ The external dimension of migration, calling for broad ranging action in the short term, geographically prioritized the African continent, in particular Sub-Saharan Africa, next to the Mediterranean region. Even though the focus was still centered upon the negative migration-development nexus and the security aspects of migration, the thematic priorities were slowly broadened to legal migration as well. However, this was left to more specific initiatives. The communication on migration and development $t^{22}$ further consolidates this new found idea of possible benefits of migration for development, while at the same time limiting the negative consequences. The second request to the Commission to present a policy plan on legal migration eventually ${ }^{23}$ resulted into the Policy Plan on Legal Migration..$^{24}$ As a consequence of the rejection by the Member States of a horizontal approach to all migrant categories, four new directives were presented. These included conditions for highly qualified workers, seasonal workers, intra-corporate transferees and remunerated trainees. It is thus clear from the outset that the opportunities for economic migration are limited to those in the interest of the Union/Member States, not addressing the request of the developing countries for legal options for lower or unskilled migrants. Moreover, it remained to be seen if the suggestions

\footnotetext{
17) Presidency Conclusions, Seville European Council, 20 and 21 June 2002 (e.g. using development aid as an instrument of pressure in negotiations concerning immigration).

18) Presidency Conclusions, Brussels European Council, 4 and 5 November 2004.

19) Communication on "A Strategy on the External Dimension of the Area of Freedom, Security and Justice", 12.09.2004, $\operatorname{COM}(2005) 491$.

20) Communication on "Priority actions for responding to the challenges of migration: First follow-up to Hampton Court", 30.11.2004, COM(2005)621.

21) Presidency Conclusions, Brussels European Council, 15 and 16 December 2005.

22) $\operatorname{COM}(2005) 390$.

23) Green Paper on an EU Approach to Managing Economic Migration, 11.01.2005, COM(2004) 811.

24) Communication on a "Policy Plan on Legal Migration", 21.12.2005, COM(2005)669. The drafted roadmap, for the remaining period of the Hague Programme (2006-2009), planned feasibility studies and proposals for 2007-2008, but it was not until 2009 effective measures/proposals were intended to be taken.
} 
made to unite both interests, such as through temporary, return and circular migration and measures to mitigate eventual brain drain, would effectively be included. The identified problems of selective national immigration policies, lack of community competence and political will on the part of the Member States for a common approach on ethical recruitment, aggravating the brain drain problem, led to specific initiatives to address the issue. ${ }^{25}$ The European Programme for action to tackle critical shortages of health workers in developing countries (PfA ${ }^{26}$ confirms the identification of Africa as a 'brain drain problem area' and provides for a set of actions on the country, regional and global level.

In sum, since the end of 2005 and during 2006, the thematic priorities of a positive migration-development nexus, and the search for more coherence as well as the geographical focus on the ACP, in particular Sub-Saharan Africa, emerged on top of the pyramid of EU priorities. As has the idea, postulated at international level, that temporary and circular migration facilitate legal migration and at the same time address the brain drain problem. This point of view is also reflected in the EU Position for the UN High Level Dialogue on Migration and Development. ${ }^{27}$ The clear emphasis on the return aspect of circular migration demonstrates however that it was still seen as an effective instrument for decreasing illegal migration in the interest of the Member States. ${ }^{28}$ The search for more coherence between the different policies, in conformity with the Policy Coherence for Development (PCD), ${ }^{29}$ and the need for concrete actions was also recognized in the European Consensus on Development. ${ }^{30}$ This demonstrates that the set policy objectives had not led to the expected results.

The Global Approach ${ }^{31}$ was strengthened geographically by including the eastern and south-eastern neighbours of the Union and for the first time circular

\footnotetext{
25) Communication on an "EU Strategy for Action on the Crisis in Human Resources for Health in Developing Countries", 12.12.2005, COM(2005)642.

26) Communication on "The European Programme for Action to tackle the critical shortage of health workers in developing countries (2007-2013)", 21.12.2006, COM(2006)870. The programme was endorsed at the GAERC Council of May 2007: 2799th General Affairs and External Relations Council meeting, General Affairs, 14 May 2007, p. 12.

27) Communication on the "Contribution to the EU Position for the United Nations' High Level Dialogue on Migration and Development", 14.7.2006, COM(2006)409.

28) S. Carrera and R. Hernandeze I Sagrera, The Externalization of the EU's labour Immigration Policy. Towards Mobility or Insecurity Partnerships?, CEPS Working Document, $\mathrm{N}^{\circ} 321$, October 2009, pp. 11-12 (32).

29) Communication on "Policy Coherence for Development - Accelerating progress towards attaining the Millennium Development Goals", 12.04.2005, COM(2005)134.

30) Joint Statement by the Council and the representatives of the governments of the Member States meeting within the Council, the European Parliament and the Commission on the European Union Development Policy: 'The European Consensus', OJ C 46/1 of 24 February 2006. The European Consensus included for the first time a common vision that guides the action of the EU, both at its Member States and Community levels, in development co-operation.

31) Communication on "The Global Approach to Migration on year one: Towards a comprehensive European migration policy", 30.11.2006, COM(2006)735.
} 
migration, mobility packages and the brain drain issue were included into one single policy. It must however be said that the inclusion of legal migration remained limited to certain categories of migrants and on a needs-based approach. The request ${ }^{32}$ to translate policy statements into solutions through concrete proposals on circular and temporary migration resulted into a framework for circular migration and mobility partnerships. ${ }^{33}$ Despite the evolution since 2006 from mobility packages to mobility partnerships, the stress seemed to remain on the interests of the Union and the participating Member States. The strict eligibility criteria, focusing on cooperation regarding illegal migration, for third countries to participate in such a mobility partnership, clearly illustrate this point. One can doubt whether developing countries, taken into account insufficient legislative and administrative means and financial resources, are able to fulfil the requirements on illegal migration. In addition, despite the emphasis on the need for full compliance with fundamental rights, earlier readmission agreements demonstrate that this commitment is at least doubtful. ${ }^{34}$ The commitments of the Union and the participating Member States were formulated in a much broader sense, e.g. "it needed to lead to improved opportunities for legal migration, based on labour needs of the Member States, and to assisting the third country to manage legal migration flows". In addition, legal migration options appear to be limited to certain categories of immigrants. The possibility to include measures for circular migration and other measures to address the risk of brain drain, were unclear and formulated in a very soft manner.

Circular migration was defined as being a form of migration that is managed in a way that allows some degree of legal mobility back and forth between two countries. ${ }^{35}$ It was argued that circular migration was a step forward in comparison to temporary migration, where the return of the migration to the country of origin was considered to be the end of the cycle. Notwithstanding the fact that circular migration was seen as an answer to create legal migration channels as well as a possible measure mitigating the risk of brain drain, the underlying reasons seemed to linger on illegal migration and to guarantee circularity, more in particular the return of those who are not or less in the interest of the Member States

\footnotetext{
32) Presidency Conclusions, Brussels European Council, 14 and 15 December 2006.

33) Communication "On Circular Migration and Mobility Partnerships between the European Union and third countries", 16.05.2007, $\operatorname{COM}(2007) 248$.

${ }^{34)}$ http://www.statewatch.org/news/2003/may/12readmission.htm, EU: Statewatch analysis no 17, Readmission agreements and the EC external migration law, consulted on 31 October 2006 and 5 April 2010; C. Billet, "EC Readmission Agreements: A Prime Instrument of External Dimension of the EU's Fight against Irregular Immigration. An Assessment after Ten Years of Practice", European Journal of Migration and Law, Issue 12 (2010), pp. (45) 71-77 (79).

35) This consists of both migrants that (temporary) return to their country of origin, but have obtained a permanent right of residence in the host country and migrants that only have a temporary right of residence.
} 
to permanently settle on their territory. ${ }^{36}$ It remains to be seen whether or not this new tool will in practice be an actual implementation of a comprehensive policy, but the policy framework was far from promising.

Notwithstanding these measures, the challenge to develop a common comprehensive immigration policy continued. ${ }^{37}$ The numerous delicate issues ${ }^{38}$ surrounding the mobility partnerships and circular migration, hamper in advance a sound implementation that takes the need for coherence and comprehensiveness into consideration. For both initiatives, the matter of the division of competence between the Community and the Member States, the integration of the development aspect into national policies, the need for a solid legal framework on mobility for circular migration and the requirement of guarantees for voluntary return, the principle of Community preference, are reoccurring issues. In identifying Moldova and Cape Verde as test cases for the mobility partnerships, the importance of differentiation, was stressed hence excluding a general legal framework concerning mobility partnerships for all third countries. In defining circular migration, a more dynamic approach does not seem to have been taken into consideration and the issue of temporariness seems to be overemphasized and the circularity aspect underexposed. ${ }^{39}$ The established principles, actions and tools towards a common immigration policy, ${ }^{40}$ taking into account the new evolutions in external relations such as the 7th Partnership on Migration, Mobility and Employment following the 2007 EU-Africa Lisbon Summit, served the same purpose. The vision of a policy based on prosperity, solidarity and security, aiming for a more coordinated, coherent, efficient and integrated approach, demonstrated the persistent aspirations.

The problem, confirming the importance of coherence and possible encroachment of migration on the priorities of the development policy, also appeared in the framework of the Millennium Development Goals (MDG). ${ }^{41}$ The analysis of

\footnotetext{
36) See note 28, CEPS Working Document, $N^{\circ} 321$, October 2009, pp. 14-15 (32). The main critique is that bilateral schemes/agreement on circularity insufficiently address the rights of the migrant and increase dependency.

37) Communication "Towards a Common Immigration Policy”, 05.12.2007, COM(2007)780; Commission Staff Working Document accompanying the Communication "Towards a Common Immigration Policy”, Interim progress report on the Global Approach to Migration, 05.12.2007, COM(2007)1632.

38) 2839th General Affairs and External Relations Council meeting, General Affairs, 10 December 2007, p. 24 et seq.

39) Circular migration is "the temporary, legal movement of people between one or more Member States and particular third countries, whereby third country nationals take up legal employment opportunities in the EU or persons legally residing in the EU go to their country of origin" (2839th General Affairs and External Relations Council meeting, General Affairs, 10 December 2007, p. 26).

40) Communication on "A Common Immigration Policy for Europe: Principles, actions and tools", 17.06.2008, $\operatorname{COM}(2008) 359$.

41) Communication on "The EU - a global player for development. Speeding up progress towards the Millennium Development Goals", 9 April 2008, COM(2008) 177 and the accompanying Commission
} 
the existing measures and debates in doctrine and praxis, ${ }^{42}$ some focusing on the need for policy changes in the developing countries (e.g. training and retention), some targeting the developed countries (e.g. recruitment), some emphasizing on the role of circular migration and temporariness ${ }^{43}$ and others doubting it, ${ }^{44} \mathrm{dem}$ onstrate that not one answer is sacred. A solution will be the result of a combination of measures. Regardless of the choices made or combinations found, the difficulty of finding legally binding and concrete actions was again brought to the table. An important fact was the recognition of the need for a combination of voluntary with structural and compulsory measures in the brain drain framework. As the analysis of the PfA shows the evolution to an actual common or even global code, with compulsory commitments, instead of unilateral and/or voluntary and non-binding schemes, such as in the UK, ${ }^{45}$ the EPSU-HOSPEEM Code of Conduct ${ }^{46}$ and the adopted WHO Code, ${ }^{47}$ seems to become more and more a utopia. Despite some positive measures, the global picture is one of insufficient implementation, coordination deficiency, problems in aid effectiveness and a lack of complete information/data. ${ }^{48}$

Following suit to actually implement the Global Approach's tenet ${ }^{49}$ a new stimulus was taken. ${ }^{50}$ The five political commitments adopted in the European Pact on Immigration and Asylum ${ }^{51}$ and also the follow up ${ }^{52}$ do not however improve

\footnotetext{
Staff Working paper, "Policy Coherence for Development. Climate Change/Energy/Biofuels, Migration and Research", SEC(2008)434/2, pp. 23-27 and pp. 30-34-35.

42) For example, some pleading for bond schemes - posing possible problems with regard tot the freedom of movement, others preferring compensation schemes - posing practical problems such as the tax payer paying the consequences instead of the private institution or encouraging migration.

43) M. Amin and A. Mattoo, "Migration from Zambia: Ensuring Temporariness through Cooperation", Washington DC: The World Bank, January 2006.

44) E.g. A. Triandafyllidou, Attempting the Impossible? The Prospects and Limits of Mobility Partnerships and Circular Migration, ELIAMEP Thesis, January 2009; http://migreurop.org/Article1627.html?lang=en.

45) http://www.dh.gov.uk/prod_consum_dh/groups/dh_digitalassets/@dh/@en/documents/digitalasset/ dh_4097734.pdf.

46) http://ec.europa.eu/employment_social/dsw/public/actRetrieveText.do?id=8639.

47) http://www.medicusmundi.org/en/contributions/news/2009/WHO_EB126_on_code_of_practice/ ?searchterm=WHO\%20Code\%20of\%20practice; 63th World Health Assembly, "WHO Global Code of Practice on the International Recruitment of Health Personnel", Agenda item 11.5, WHA63.16, 21 May 2010.

48) Commission Staff Working Document, "European programme for action to tackle the critical shortage of health workers in developing countries (2007-2013) - Progress report on implementation", 16.09.2008, SEC(2008)2476.

49) The external dimension of the Union's common migration policy in dialogue and partnership with third countries, uniting the management of legal migration, control of illegal migration and make migration a positive force for development.

50) Communication on "Strengthening the Global Approach to Migration: Increasing coordination, coherence and synergies", 08.09.2008, $\operatorname{COM}(2008) 611$.

51) Note from the Presidency to the Council, "European Pact on Immigration and Asylum", 24 September 2008.

52) Council Conclusions on the follow-up of the European Pact on Immigration and Asylum (3018th General Affairs and External Relations Council meeting, 3 June 2010).
} 
much to the picture. For example, the Pact emphasizes the importance of attraction for highly qualified workers, confirming the problem of selective economic migration. Moreover, the priority areas show a clear commitment on fighting illegal migration. The balanced approach leading to an actual partnership seems thus a distant perspective. The overview of geographical focus on the African continent proves that a framework had been set, now its implementation needed to be guaranteed.

Within the prospect of a new five year programme, the Hague Programme was subjected to an evaluation. ${ }^{53}$ After the summary of achievements - such as the Blue Card Directive, ${ }^{54}$ a better integration of migration into development policy and other policy domains, enhancing the dialogue and cooperation with e.g. Africa, and new tools such as the mobility partnerships, and an overview of some crippled ambitions - such as in the area of legal migration, ${ }^{55}$ the overall conclusion was that progress had been made. Although some drawbacks, in particular finding a balanced approach and time needed to move on from policy pledges to action, taken as a whole these initiatives may indeed be seen as stepping stones to a comprehensive migration policy. In the drafting of the new programme a lot of emphasis was put on the external dimension. The envisaged dynamic immigration policy ${ }^{56}$ included extending the dialogue and cooperation to other areas such as the Caribbean, without losing sight of the priority areas. In general, the suggestions made come down to an actual implementation of the Global Approach and its new tools. Apparently the listed priorities seem to tip the balance of migration policy in exploitation to the benefit of the EU and the Member States and less in coherence with the development principle.

The Stockholm Programme (2010-2014), ${ }^{57}$ endorsed by the European Council in December 2009, ${ }^{58}$ and the proposed Action Plan ${ }^{59}$ do not only include the

\footnotetext{
53) Communication on "Justice, Freedom and Security since 2005: An evaluation of the Hague Programme and Action Plan”, 10.06.2009, COM(2009)263.

54) The directive is considered to be not much more than a first step towards harmonization, pointing out the limited possibilities to move and reside between Member States as a set back. The issue of brain drain is not mentioned. SEC(2007)766, p. 21.

55) Identifying the unanimity rule as one of the reason not more ambitious and long term results have been achieved. See: SEC(2007)766, p. 20.

56) The vision of the dynamic immigration policy further includes a concerted policy better in line with labour-market requirements of the Member States and is seen as a proactive policy based on a European status for legal immigrants and the control of illegal immigration.

57) Note from the Presidency to the General Affairs Council and European Council, "The Stockholm Programme - An open and secure Europe serving and protecting the citizens", 2 December 2009.

58) European Council, Conclusions, 10 and 11 December 2009.

59) Communication on "Delivering an area of freedom, security and justice for Europe's citizens. Action Plan Implementing the Stockholm Programme", COM(2010)171. The Council notes that some suggestions made by the Commission are not in line with the Stockholm Program and others are not reflected in the Communication and urges the Commission to take only those initiatives that are in full conformity with the Stockholm Programme (Council Conclusions on the Commission Communication "Delivering
} 
external dimension in the general framework, but also incorporate the new Lisbon treaty provisions. The Programme and Action Plan confirm the need for a comprehensive and sustainable European migration and asylum policy framework and consolidate the Global Approach. The mobility partnerships and circular migration remain important tools and initiatives are suggested to include other legal migration options. It is however clear that security concerns cover the majority of issues considered and that there is not only a continuing need for more coherence, but also for a further development and an actual implementation of the comprehensive approach. In analyzing the Stockholm Programme and its suggested Action Plan, it becomes apparent that the internal-external/securitymobility-development balance is still not reached.

Sequential stepping stones to a comprehensive common migration policy have been taken. An evolution from an internal to an external dimension in dialogue and partnership with third countries, has taken place, encompassing not only elements concerning illegal migration but also on legal labour migration and mainstreaming migration into development to the benefit of both. Nevertheless, speaking of a major leap from security to legal mobility for the high and the lower skilled and migration serving both partners, also mitigating the negative effects, would go too far. It is only fair to conclude that ambitious policy objectives have been set and the first steps to a common and balanced approach have been taken, but there is still a long way to go. ${ }^{60}$ Foundations are laid, but problems such as coherence and the fear of Member States losing control over their labour markets, have hampered the translation of pledges into tangible achievements and the creation of a common comprehensive approach.

\section{Legal Commitments on Economic Migration Jeopardizing the Development of Third Countries?}

Policy frameworks are not an end in itself, they need to be reflected by legal binding commitments. This section will address whether the search over the years for a comprehensive approach knows a similar evolution in the legal framework, and what options have been found to combine mobility in the interests of both, without putting development at risk.

an area of freedom, security and justice for Europe's citizens - Action Plan Implementing the Stockholm Programme" (COM(2010)171final), 3018th General Affairs and External Relations Council meeting, 10 June 2010.

60) This is also confirmed in the Mid-Term review of the Thematic Programme "Cooperation with third countries in the areas of migration and asylum" (Issues Paper, 18.03.2010) identifying the balancing of the three dimensions of the Global Approach as one of the main challenges ahead, mainly by improving labour migration and mobility for third country nationals. This requires a more long term, strategic and evidence based policy on migration. 


\subsection{Legal Commitments: In Search for The Right Combination}

The mobility of third country nationals can be facilitated through visa requirements, however not creating (new) channels for migration or a right of entry. ${ }^{61}$ The regulation on short stay visa contains visa exemptions for certain categories, e.g. for school pupils in the context of a school excursions. The reluctance of the Member States is again illustrated by Article 4, making it possible to provide for an exception from the exemption of visa requirements for Annex II nationals carrying out a paid activity during their stay. ${ }^{62}$ Only recently, nationals from Antigua and Barbuda, Bahamas, Barbados, Mauritius, Saint-Kitts and Nevis and Seychelles (all ACP countries) were exempted from the visa requirement upon conclusion of bilateral agreements. Such a short-stay visa waiver agreements were signed in May 2009 and provisionally applied from 28 May 2009 on. ${ }^{63}$ However, this visa waiver is clearly limited in scope, exempting all persons travelling for the purpose of carrying out a paid activity, covering persons entering for the purpose of a remunerated activity as an employee or as a service provider. ${ }^{64}$ The actual use of the possibility to require a visa for persons carrying out a paid activity during their stay, gives evidence of a slightly different image regarding the reluctance of the Member States. ${ }^{65}$ The notifications provided for by the Member States demonstrate that for the abovementioned countries 'only' half of the Member States (25) actually apply this visa requirement. ${ }^{66} \mathrm{~A}$ nuance must thus be made with regard to the Member States' position. Nevertheless, this possibility remains a choice of the individual Member State and creates differences between the Member States. Another option facilitating movement based on one's occupational status is the possibility of the multiple-entry visa that can be valid for one, two or multiple entries, with a maximum validity of five years. The issuance of such a visa is however dependent on the proven need to travel frequently and 'integrity

\footnotetext{
${ }^{61)}$ See: S. Peers, "Key Legislative Developments on Migration in the European Union", European Journal of Migration and Law, Issue 9 (2007), pp. (229) 234-235 (251).

62) Council Regulation (EC) No 1932/2006 of 21 December 2006 amending Regulation (EC) No 539/ 2001 listing third countries whose nationals must be in possession of visas when crossing the external borders and those whose nationals are exempt form that requirement, OJ L 29/10 of 3 February 2007.

63) E.g. Council Decisions of 6 April 2009 on the signing and provisional application of the Agreement between the European Community and the Federation of Saint Kitts and Nevis on the short-stay visa waiver, OJ L $169 / 37$ of 30 June 2009.

64) Based on the Joint Declarations of the respective agreements: some businesspersons, sportspersons and artists, journalist and intra-corporate trainees are normally not covered (L 169/38) and are thus exempted from a visa requirement.

65) Information pursuant to Council Regulation (EC) No 539/2001 of 15 March 2001 listing the third countries whose nationals must be in possession of visas when crossing the external borders and those whose nationals are exempt from that requirement, Exceptions to the exemption from the visa requirement by virtue of Article 4(3), 25-29. (http://ec.europa.eu/home-affairs/doc_centre/borders/ docs/notification_visa_539_2001_en.pdf, consulted on 1 December 2010).

66) The Member States in this case, with the exemption of the United Kingdom and Ireland, that do not apply the Regulation.
} 
and reliability'. ${ }^{67}$ The evolution in the EU's visa regime is not further restricting mobility, but the exemptions are strict and leave persons carrying out a paid activity in the hands of the Member States.

Following the communication on a community immigration policy, ${ }^{68}$ the directive on the status of long-term residents ${ }^{69}$ was the first initiative in the area of conditions of admission and residence since the entry into force of the Amsterdam Treaty. It is more a measure in the framework of guaranteeing successful integration. Besides that, a lot was left to the Member States. Only a very small step was taken by providing that a third country national does not necessarily lose the possibility for a long-term resident status because of temporary absence of the territory of a Member State (Articles 4 and 9). It thus provides a small possibility of circularity, but it does not lead to a real facilitation of mobility. The directive, being a reflection of the policy framework of that time, lacks a clear development connection. The directive on family reunification ${ }^{70}$ is in keeping with that.

In absence of a common approach on labour migration, initiatives were adopted for specific categories of migrants, namely a directive concerning migration for study purposes, pupil exchange, ${ }^{71}$ unremunerated trainees and voluntary services ${ }^{72}$ and one concerning researchers. ${ }^{73}$ Both concern migration categories that are by definition temporary and respectively Articles 12 to 15 and Article 8 limit the residence permit to a specified period of time. Researchers can be considered 'temporary migrants' by their very nature. Their activities are in general confined to specific projects and timing, they move around frequently and settle for different periods of time in different countries. ${ }^{74}$ Overall, the course of their career is characterized by short term contracts and mobility should be considered an added value on their $\mathrm{CV}{ }^{75}$ The suggestion to facilitate the issuance of short term visa

\footnotetext{
67) Regulation (EC) No 810/2009 of the European Parliament and of the Council of 13 July 2009 establishing a Community Code on Visas (Visa Code), OJ L 243/ of 15 September 2009, Article 24, paragraph 1 and 2. (Applicable form 5 April 2010)

68) $\operatorname{COM}(2000) 757$.

69) Council Directive 2003/109/EC of 25 November 2003 concerning the status of third-country nationals who are long-term residents, OJ L 16/44 of 23 January 2004.

70) Council Directive 2003/86/EC of 22 September 2003 on the right to family reunification, OJ L 251/12 of 3 October 2003.

71) May be limited by Member States on a reciprocity basis (Article 9 (2)).

72) Council Directive 2004/114/EC of 13 December 2004 on the conditions of admission of third country nationals for the purposes of studies, pupil exchange, unremunerated training and voluntary services, OJ L 375/12 of 23 December 2004. (A Spring 2009 proposal suggested to extend the directive to remunerated trainees and au-pairs).

73) Council Directive 2005/71/EC of 12 October 2005 on a specific procedure for admitting thirdcountry nationals for the purpose of scientific research, OJ L 289/15 of 3 November 2005.

74) Communication on "The presentation of a proposal for a directive and two proposals for recommendations on the admission of third-country nationals to carry out scientific research in the European Community", 16.03.2004, COM(2004)178, 5.

75) Commission Staff Working Document Accompanying document to the Communication "Better
} 
further endorses this point and moreover is in conformity with the need to take into consideration the possible detrimental effects on third countries, namely the brain drain issue, and the need for circularity and the maintenance of contact with the country of origin. ${ }^{76}$ However, analyzing the preparatory work for the directive as well as the linked recommendations and the final versions, it appears that the temporary aspect of this kind of migrants, nor circularity for that matter, is necessarily a priority issue for the Union/Member States. Several measures appear to be aimed at attracting and keeping these third country nationals. ${ }^{77}$ Despite the recognition of possible brain drain problems for developing countries, the expressed concerns and suggestions on this matter have not received any legal follow up. ${ }^{78}$ There is little coherence with other legislative initiatives and no provisions that ensure the contribution to the development in the host country. The preamble of the directive concerning researchers, brings to mind that the implementation of the directive may not encourage the brain drain from emerging or developing countries, referring to necessary back-up measures such as the reintegration of the researcher in the host country and measures concerning the movement of researchers in partnership with third countries. This vague statement

Careers and more mobility: a European partnership for researchers", Impact Assessment, SEC(2008)1911, 14,20 and 60.

76) $\operatorname{COM}(2004) 178,4$ and 42 (46); Report on the proposal for a Council directive on a specific procedure for admitting third-country nationals for purposes of scientific research, on the proposal for a Council recommendation to facilitate the admission of third-country nationals to carry out scientific research in the European Community and on the proposal for a European Parliament and Council recommendation to facilitate the issue by the Member States of uniform short-stay visas for researchers from third countries travelling within the European Community for the purpose of scientific research, A6-0054/2005 final, 01.04.2005, 23 and 30 .

77) Article 8 of the directive is the provision concerning the duration of the residence permit (at least one year or if less, for the duration of the project). However this permit can be renewed if the conditions are still met, meaning also when a new hosting agreement is signed, without any time limitations nor flanking measures to address possible consequences in the country of origin. Other examples are: Article 13 provides for a facilitation of mobility within the Union and Article 9 concerns the family members of the researcher. Although the proposal did not consider this matter, the issue was dealt with under Directive 2003/86, the proposal for a recommendation (issued pending the implementation of the directive) did and underlined the very important factor of family reunification for researchers of third countries who plan to settle in Europe. $\mathrm{COM}(2004) 178,5$ and 34 . In the final version of the recommendation $(O J \mathrm{~L}$ $289 / 26$ of 3 November 2005) this was weakened and despite the fact that in the final version of the Directive (Article 9) this remains an option for the Member States, it is clear this contributes to the facilitated integration of the third country researcher. The proposal for the recommendations advocates the Member States to abstain from putting a time limit on the admission to the labour market and aims to ensure that residence permits can be renewed without (major) restrictions. $\operatorname{COM}(2004) 178,34$ and 39, points 1(c) and 2(b). Also points 1(c) and 2(b) in the final version.

78) Reflections on possible brain drain problems can be found in: consideration 6 in the proposal for the Directive, the proposal for the recommendation explicitly provided for derogations in case of measures at counteracting the brain drain. $\operatorname{COM}(2004) 178,23$ and 34-39, points 1(c) and 2(b). Also in: Opinion of the Committee of the Regions on the Communication, OJC 71/1 of 22 March 2005, points 1.3. and 1.15 and the Opinion of the European Economic and Social Committee, OJC 120/60 of 20 May 2005, points 3.9.1. and 3.9.2. 
did however not lead to clear commitments in the directive, nor offered guarantees that the acquired skills can actually benefit the country of origin. ${ }^{79}$ Moreover, it appears from the Communication on circular migration and mobility partnerships that not enough measures were incorporated to guarantee actual circularity. In addition the Committee of the Regions, in the framework of the Blue Card Directive (infra), pointed out that according to reports of the International Labour Organisation (ILO), initiatives for the admission of skilled workers, amongst those the measures of the Commission concerning circular migration, "tend to intensive brain drain concerns". ${ }^{80}$

In line with the horizontal approach of the Policy Plan on Legal Migration, the directive for highly qualified professionals finally took form. ${ }^{81}$ In taking stock of the best options available, it appeared that a balance between positive effects for the proper market and negative effects for the source country is not easy to find and that whatever the option taken accompanying measures would be necessary to address the negative consequences. ${ }^{82}$ Following the manifestation of the reality of the brain drain problem, in particular from Sub-Saharan Africa and the Caribbean, ${ }^{83}$ it is only logic that the proposal on the directive ${ }^{84}$ was received with much reservation. ${ }^{85}$ Criticism and concerns on the consequences in aggravating the brain drain problem were refuted by the argument that the directive would contain provisions on ethical recruitment, in the form of limitation or even a ban, and by measures that assure circular migration. ${ }^{86}$ The Blue Card directive was

\footnotetext{
79) In the preamble of the recommendation of the Council to facilitate admission for third-country nationals to carry out scientific research in the European Community, similar wordings can be found (consideration 8). Suggestions to provide derogations from the general rule to renew and provide for work en residence permits for an unlimited period of time based on the need of the country of origin were not kept in the final version. It was considered that these provisions lacked the clarity and precision required for a legal text. Still, no valuable alternative was made to address possible brain drain problems. COM(2004)178, 34-39; Report of the European Parliament, A6-0054/2005 final, 01.04.2005, 20-21 and 45-46.

80) Opinion of the Committee of the Regions on "A global approach to migration: developing a European policy on labour immigration in conjunction with relations with third countries", OJ C 257/20 of 9 October 2008, point 59. Also the Opinion of the EESC on 'EU immigration and cooperation policy with countries of origin to foster development' (OJ 44/91 of 16 February 2008) reflects the lack of a sound legislation concerning circular migration.

81) I would like to thank dr. Daniel Wunderlich for his comments and suggestions regarding the contribution of the EP, in the framework of the UACES Conference in Bath, February 2010.

82) Proposal from the Commission, Commission Staff Working Document Accompanying to the Proposal for a Council Directive on the conditions of entry and residence of third country nationals for the purpose of highly qualified employment, Impact assessment, 23.09.2007, SEC(2007)1403.

83) In percentages: $45,59 \%$ of high skilled workers comes from 'Other Africa' (p. 11) (other numbers on p. 109 suggest $43,39 \%$ ) and $8,54 \%$ from the Caribbean.

84) Proposal for a Council Directive on the conditions of entry and residence of third-country nationals for the purpose of highly qualified employment, 23.09.2007, COM(2007)637.

85) E.g. 6th Ordinary Session of the Labour and Social Affairs Commission of the African Union, 21-25 April 2008, Addis Ababa, Ethiopia, "Progress Report on the Follow-up of the Implementation on Migration Instruments".

86) $\operatorname{COM}(2007) 248$ and Justice and Home Affairs, 2827th Council meeting, Brussels, 8 and 9 Novem-
} 
presented as the answer to enhance the competitiveness of the EU economy and at the same time limit brain drain from developing countries. Nonetheless the European Pact, in its commitment on legal migration, already seemed to be a 'bad' herald on the actual commitments in the directive, stressing the importance of attractiveness, but not putting the same stress on the brain drain problem. ${ }^{87}$

Finally the long-lasting exploration for an instrument addressing economic immigration resulted into the so-called Blue Card Directive ${ }^{88}$ and the preamble (considerations 21, 22 and 24) seemed promising. ${ }^{89}$ The identification of what was considered highly qualified employment was not unanimous amongst the Member States and was not an easy concept to define. From the definition in Article 2 it appears clearly that only employees who have adequate and specific competences proven by higher professional qualifications, namely diploma or acquired professional experience, are covered. Further eligibility criteria are set out in Article 5. Some third country nationals are excluded from the scope of the directive, e.g. those entering under the GATS provisions (infra, section 4). ${ }^{90}$ For the first time specific provisions were included to address the brain drain problem. Where the Commission proposal ${ }^{91}$ was a good starting point, the commitments were strengthened by adding some amendments made by the European Parliament. ${ }^{92}$ The importance of ethical recruitment and cooperation with the third country involved appears clearly from recital 20 of the preamble in the

ber 2007; 10th Africa-EU Ministerial Troika Meeting, Brussels, 16 September 2008, Communiqué 13121/08 (Presse 260).

87) http://www.immigration.gouv.fr/IMG/pdf/Plaquette_EN.pdf; Note from the Presidency to the Council, "European Pact on Immigration and Asylum", 24 September 2008, p. 5.

88) Council Directive 2009/50/EC of 25 May 2009 on the conditions of entry and residence of thirdcountry nationals for the purposes of highly qualified employment, OJ L 155/17 of 18 June 2009. The directive was adopted under the old Article 63 (3,a) and 4 TEC.

${ }^{89)}$ It appears already from the preamble of the proposal however that initially more emphasis was put on the brain drain issue, with special mention of Sub-Saharan Africa. This was not incorporated in the final version.

90) In the Commission's proposal Article 3(f) refers "to third country nationals entering a Member State under commitments contained in an international agreement facilitating the entry and temporary stay of certain categories of trade and investment-related natural persons". The EP, amendment 20, explicitly added "in particular intra-corporate transferees, providers of contractual services and trainees with higher education qualifications who are covered by the Community's obligations under the GATS". Despite the fact that this specification was not included in the final Article $3(\mathrm{~g})$ it is clear that this implies a referral to the commitments under the GATS.

91) $\operatorname{COM}(2007) 637$.

92) European Parliament legislative resolution of 20 November 2008 on the proposal for a Council directive on the conditions of entry and residence of third-country nationals for the purpose of highly qualified employment (COM(2007)637 - C-6-0011/2007 - 2007/0228(CNS)), OJ C 16 E/224 of 22 January 2010. The Committee on Development (Opinion (3.9.2008) for the Committee on Civil Liberties, Justice and Home Affairs) clearly raised the stakes on the problematic consequences of the directive on the brain drain problem, the lack of strong legal commitments and the problems surrounding circular migration (e.g. stimulating circular migration through dual citizenship and mutual recognition of diplomas). 
amendments. ${ }^{93}$ The suggestion made by the Commission ${ }^{94}$ to include the possibility that professions listed in any agreement between the Community or the Community and its Member States on the one hand, and one or more third countries, on the other hand, do not fall under the Directive if so agreed, in order to assure ethical recruitment and the protection of human resources in the signatory third state, was included (Article 3, paragraph 3). However, there was an important change made to the proposal. ${ }^{95}$ In the final version the Article changed the possibility of such an agreement to agreements between the Community and/ or Member States. Hence, the possible conclusion of such an agreement can now be a unilateral measure by a Member State, encompassing possible coordination problems. Even though this reflects the commitment to address the negative consequences, this provision is too weak and leaves too much in de hands of the Member States offering no legal certainty. Up until now no such agreements were concluded, nor were specific clauses included into recent agreements (see e.g. the EPA). In the same sense, but based on national decisions, a Member State may refuse an application to ensure ethical recruitment in vulnerable sectors (Article 8, paragraph 4). This amendment (35), made by the EP is again an important step forward towards tackling the brain drain problem, but again containing no actual obligation, only including a possible ground for refusal, and leaving it strongly dependent on the Member States decision. The only actual strong commitment suggested by the EP on the issue in Article $5 \mathrm{bis}^{96}$ was not incorporated in the final version of the directive. ${ }^{97}$ The conclusion may be that the additional amendments suggested by the EP show for a stronger commitment, but the eventual results are weak obligations or rather only possibilities and there are no legal consequences for not applying principles of ethical recruitment. The provisions should have been combined with compulsory conditions or an EU Code of Conduct on Ethical recruitment which is transparent, binding and applicable to all Member States. Furthermore, Article 5 holds the criteria for admission and provides in paragraph 3 for a salary threshold. This threshold may however be low-

\footnotetext{
93) The final version of recital 22 in the directive bears closer resemblance to the Commission's suggestion than the EP's, but the specific referral to Africa-EU Declaration on Migration and Development (Tripoli) as well as the quest for a comprehensive migration policy was not taken on.

94) SEC(2007)1403, p. 65.

95) The suggestion made in amendment 22 by the EP to add explicitly "the sectors vital to achieving the UN MDG, in particular the health and education sectors, and in sectors vital to the ability of developing countries to deliver basic social services" was not included.

96) "Avoiding shortage of highly qualified workers in third countries. The MS shall not actively seek to attract highly qualified workers in sectors that are already subject, or are expected to be subject, to a shortage of highly skilled workers in the third country. This applies to the health and education sectors in particular."

97) The implications made in recital 20 of the EP's amendments for compensations measures ("Member States should offer concrete support for training of professionals in key sectors weakened by the exodus of talent"), just as European Economic and Social Committee (EESC) suggested (Opinion of the EESC on 'EU immigration and cooperation policy with countries of origin to foster development', OJ 44/91 of 16 February 2008, point 9.12.), have no reflection in the Directive.
} 
ered for employment in professions which are in particular need of third country national workers and which belong to the major group 1, managers, and group 2, professionals, of the ISCO (International Standard of Occupation Classification). ${ }^{98}$ The latter also includes for example, health professionals and teaching professionals. This seems to be in contradiction with any effort to mitigate brain drain.

In addition and to promote circular migration, ${ }^{99}$ derogation from the periods of absence from the territory of the Member States to obtain and retain the status of long-term resident, are provided for (Article 16, paragraphs 3 and 4). The Commission constrained this possible derogation to situations where the third country national could present evidence that he/she had been absent from the Community territory to exercise an economic activity in an employed or selfemployed capacity, or to perform a voluntary service, or study in his/her own country of origin (preamble 17 and Article 17). The EP considered these conditions however an additional administrative burden, creating disproportionate difficulties. In the final version of Article 16, paragraph 5 these compulsory conditions of proof have been changed into an option. This creates a much broader option of circularity, making it also possible to temporarily return to the country of origin for family or personal reasons. ${ }^{100}$ However an additional change in the final provision (Article 16, paragraph 5) again requires a refining of the relevance in the brain drain framework. Whereas in the proposal and the EP resolution it was an obligation (the derogations shall apply only when these conditions are fulfilled), this commitment evolved again into an instrument of the Member States where "the derogation may be restricted to cases where such a proof of return to an economic activity in an employed or self-employed capacity, or to perform a voluntary service, or study" is given. On the one hand, the additional changes are a positive evolution broadening the scope for an eventual circular migration; on the other hand, they again leave much uncertainty on their application and create possible differences between the Member States. Furthermore, there is no guarantee for a positive contribution to the development of the country of origin. Besides, there is a limited coordination between the different directives. Nothing is hindering e.g. students or researchers to stay after their studies or hosting agreements under the Blue Card Directives, if they comply with the set criteria and if the Member State in question so allows. ${ }^{101}$

Finally, the implementing measures (Article 20), in particular the communication of information from the Member States who apply the possible refusal of an application based on Article 8, paragraph 4 (supra), allow to monitor recruitment

\footnotetext{
98) http://www.ilo.org/public/english/bureau/stat/isco/docs/resol08.pdf.

99) In principle the standard period of validity of the EU Blue Card is temporary, but this can be renewed and the acquiring of a long-term resident status is facilitated.

100) As was suggested by the EP in amendment 8 (recital 17 preamble). It is however remarkable that these conditions of proof were not removed in the relevant provision (amendment 52, Article 17).

101) This appears clearly form consideration 8 of the preamble of the directive.
} 
policies in developing countries. However in the annual report, due by 19 June 2013, there is no obligation to include impact assessments on brain drain nor to provide possible counteracting measures. The calls for more compulsory measures ${ }^{102}$ were not followed up and resulted in impoverished provisions in the Blue Card Directive.

Despite the Commission's referral to the need of both skilled and unskilled, ${ }^{103}$ up until now no final legislation to facilitate mobility for this last category has been adopted. In conformity with the Policy Plan on Legal Migration one proposal intended for low(er) skilled workers, namely seasonal workers, and another for non-EU skilled workers of multinational concerns, namely intra-corporate transferees (ICT), have been tabled, but have not been poured into a final version yet. ${ }^{104}$ The proposal for seasonal workers is directed at a specific category of seasonal temporary migrants. The directive would also allow the removal of obstacles to legal migration for non- and low skilled workers. ${ }^{105}$ It is intended to contribute to the effective management of migration flows. ${ }^{106}$ The eligibility criterion that defines a seasonal worker is based on "the passing of the season"; the activity is tied to a certain time of the year by an event or pattern during which labour levels rise far above the usual. ${ }^{107}$ Agriculture and tourism are the sectors most commonly referred to, ${ }^{108}$ but nothing is excluding the possible application on other sectors and it is up to the Member States to fill in these criteria. On the one hand, the directive would remain limited to a certain category of legal migrants. On the other hand, the definition however does not contain elements concerning the non- or low skilled aspect. It is assessed that young and educated third country nationals often migrate and as a consequence this might imply the risk of a temporary brain drain. ${ }^{109}$ In addition, when no alternative is present, this might result in 'brain waste'. The goal of the directive is not only to protect a weaker category of workers, a sector that is characterized by illegal employment and most vulner-

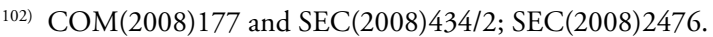

103) The need not only for (highly) skilled, but also for lower and unskilled was also brought to the attention by the Committee of the Regions (OJ C 257/20 of 9 October 2008), point 53 and the EESC (SOC/300), point 1.3 and opinion of the EESC on 'EU immigration and cooperation policy with countries of origin to foster development', OJ 44/91 of 16 February 2008, points 10.1 and 10.3.

104) http://ec.europa.eu/atwork/programmes/docs/forward_programming_2010.pdf. These measures will be taken based on the new Lisbon rules of c-decision and qualified majority.

105) Proposal for a Directive of the European Parliament and of the Council on the conditions of entry and residence of third-country nationals for the purpose of seasonal employment, COM(2010)379, 13.07.2010, 2 and 6.

106) Consideration 6 of the proposal $(\operatorname{COM}(2010) 379,14)$ and Commission Staff Working Document, Impact Assessment accompanying the Proposal for a Directive of the European Parliament and of the Council on the conditions of entry and residence of third-country nationals for the purpose of seasonal employment, SEC(2010)887, 13.07.2010, 18.

107) Art. 3 (b) and (c) of the proposal.

108) E.g. consideration 10 in the preamble of the proposal.

109) $\operatorname{SEC}(2010) 887,26$.
} 
able for exploitation and bad working conditions, ${ }^{110}$ but it is also aimed at contributing to the development of the country of origin, addressing the central goal of poverty alleviation and the attainment of the MDG, thereby complying with the EU development policy. ${ }^{111}$ It is expected to realize this objective by ensuring flexible rules that guarantee temporary legal migration, and as such no major brain drain issues are likely to occur, and by promoting circular migration facilitating reliable inflows of remittances and transfer of skills and investment. ${ }^{12}$ Although the proposal does not state a maximum duration of work permit per stay, the provisions in Article 11, setting the maximum at six months per calendar year (paragraph 1), clearly indicate that it only concerns actual seasonal work and hence temporary migration. Several measures (incentives and safeguards) have been taken to avoid temporary migration becoming permanent. ${ }^{113}$ Article 11 , paragraph 1 contains an obligation of return for the seasonal worker. The provision in paragraph 2 that allows for an extension of the contract, within the maximum period, and the possible change of employer was included to reduce the risk of overstaying and it is assessed that this will allow higher earnings and remittances sent home, which contributes to the development of the country of origin. ${ }^{114}$ The measure to facilitate re-entry (Article 12) should be an additional incentive to return to the country of origin (infra). A safeguard to ensure that the migration is temporary, is the sanction foreseen in Article 12, paragraph 2 that the seasonal worker is to be excluded from admission for one or more years if he/ she does not comply with the obligations, in particular the obligation to return. In the same sense, an employer who has not fulfilled the obligations arising out of the work contract, shall be excluded from application for seasonal workers. This in combination with Directive 2009/52 115 should be a disincentive for temporary migration becoming permanent. ${ }^{116}$ The suggestion of a reporting obligation upon return in the country of origin was discarded based on financial considerations and doubts on the feasibility of this solution. ${ }^{117}$ The circularity aspect is included through the facilitation for re-entry (consideration 17 and Article 12, paragraph 1 ), by providing a multi-seasonal work permit or a facilitated procedure for seasonal workers who were admitted to that Member State and apply to be admitted as such in a subsequent year. Making circularity dependent on compliance with

\footnotetext{
110) SEC(2010)887, 13-14.

111) Policy Plan on Legal Migration, COM(2005)669, 3 and 7; SEC(2010)887, 17.

112) $\operatorname{COM}(2010) 379,3$; SEC(2010)887, on the possible positive contributions for developing countries: pp. 24-25, 28-29, 30-34 and 34-39.

113) $\operatorname{COM}(2010) 379,2 ; \operatorname{SEC}(2010) 887,11$.

114) $\operatorname{COM}(2010) 379,10$.

115) Directive 2009/52/EC of the European Parliament and of the Council of 18 June 2009 providing for minimum standards and measures against employers of illegally staying third-country nationals, OJ L 168/24 of 30 June 2009.

116) Consideration 6 preamble of the proposal.

117) SEC(2010)887, 20, 30 and 39.
} 
the obligation of return (Article 12, paragraph 2) again demonstrates the securitized vision of immigration. ${ }^{118}$ Moreover, it appears that the actual circularity and hence the contribution to the development of the country of origin is again in the hands of the Member States. ${ }^{119}$ It appears that the safeguards for return are stronger than the possibility of circularity. These measures seem yet another example of failed circularity. In the analysis above, it is demonstrated that the proposal at least suffers from a few remaining flaws. However, it is too early to draw conclusions and a lot will depend on the final version of the directive, as well as on the implementation in practice. It must nonetheless be mentioned that in referring to the commitment of the Union towards the legal options for labour migration, reference is again made to the requirement of a strong(er) commitment from the countries of origin in tackling irregular migration. ${ }^{120}$

In comparison, the proposal for a directive for intra-corporate transfers is directed at highly skilled and qualified third country nationals. In relation to the GATS, in particular mode 4 (infra, section 4.2), the directive is presented as a complement to the international commitments, as the GATS does not contain provisions on entry, stay and residence. ${ }^{121}$ The facilitation of intra-corporate transfers is described as an objective, which is also shared by EU trade policy. The existing difference between the Member States in entry procedures and temporary residence rights is considered an obstacle for the uniform application of the international commitments. ${ }^{122}$ Hence, the provisions in the (proposal) directive facilitate the fulfilment of the international commitments under the GATS, as well as commitments in agreements such as the EPA with the CARIFORUM States. ${ }^{123}$ As a consequence, the definitions in the proposal were aligned with the ones used under the GATS. ${ }^{124}$ Logically, the definitions of the targeted categories, namely managers, specialists and also graduate trainees (Article 3 ), in general concur with the definition of 'key personnel' used in the EPA with the

\footnotetext{
118) See note 28, CEPS Working Document, $\mathrm{N}^{\circ} 321$, October 2009, p. 15.

119) Certainly in combination with the possible grounds of refusal in Article 6 (economic needs test, quota, EU preference).

120) $\operatorname{COM}(2010) 379,6$; $\operatorname{SEC}(2010) 887,14$ and 16.

121) Proposal for a Directive of the European Parliament and of the Council on conditions of entry and residence of third-country nationals in the framework of an intra-corporate transfer, $\operatorname{COM}(2010) 378$, 13.07.2010, 2-4 and 14 (recital 10 preamble); Commission Staff Working Document, Impact Assessment accompanying the Proposal for a Directive of the European Parliament and the Council on conditions of entry and residence of third country nationals in the framework of an intra-corporate transfer, SEC(2010)884, 13.07.2010, 20-21.

122) $\operatorname{COM}(2010) 378,7 ; \operatorname{SEC}(2010) 884,17$ and 19.

123) $\operatorname{COM}(2010) 378,2-4$ and 14 (recital 10 preamble); $\operatorname{SEC}(2010) 884,20-21$. This also means that the directive does not contain a right of admission and the Member States remain competent to determine the volumes of admission, but this must be used in accordance with the commitments resulting from international agreements facilitating the entry and temporary stay of certain categories of trade- and investment-related natural persons, $\operatorname{COM}(2010) 378,10$.

124) $\operatorname{SEC}(2010) 884,6$ and 8 and 21.
} 
CARIFORUM States (Article 81). ${ }^{125}$ In general, the scope of the directive is broader, in the sense that also intra-corporate transfers in the non-service sector as well as from third countries, who are not party to a trade agreement, are targeted. ${ }^{126}$ This proposal is directed at a special category of migrants, being third country nationals who are still employees of their country of origin, who fulfil an assignment for a defined period of time in order to address specific short term needs of the company. ${ }^{127}$ Hence, they can be considered temporary migrants in principle. The temporary nature is guaranteed by the required proof of evidence that the transferee will be able to transfer back to an entity belonging to that group of undertakings and established in a third country at the end of the assignment (recital 13 preamble and Article 5, paragraph 1 (b)). Secondly, the granted permit is limited to a maximum of three years for managers and specialists and one year for graduate trainees (Article 11, paragraph 2), as is the case in the EPA CARIFORUM (Article 81, paragraph 1). ${ }^{128}$ It is assessed that in general most ICT come from developed or emerging countries and thus the brain drain implications are not considered to be a major issue. ${ }^{129}$ In addition, as the migration is only temporary, a possible brain drain from developing countries is limited in time. Moreover, the directive is considered beneficial to the country of origin due to transfers of skills, knowledge, technology and know-how and encourages brain circulation. ${ }^{130}$ Notwithstanding the fact that the impact on developing countries is considered to be limited, it may at least be considered that this directive, in combination with the Blue Card Directive (see also section 4.2.), might be a first step for permanent migration for the highly skilled/qualified. ${ }^{131}$ This possibility is also recognized in the Commission's impact assessment, referring to

125) Only slight differences can be noticed. Such as the fact that the definition on intra-corporate transfers (Article 80 EPA CARIFORUM) contains a one year employment requirement before transfer as in the directive a 12 month criterion is included in the admission criteria of Article 5, paragraph 1 (b). Also in the definition on graduate trainees there is a small specification that the training should aim at preparing the transferee for a managerial position (compare Article 80 EPA CARIFROUM with Article 3 (g) of the proposal for a directive).

126) $\operatorname{COM}(2010) 378,9$ and 14 (consideration 10 preamble). In general, because the broader scope of the directive does not hold for the EPA CARIFORUM. In that agreement the temporary presence of ICT is not necessarily linked to the supply of services. In comparison to the movement of contractual service suppliers and independent professionals, that is limited to the supply of specific services (Article 83). B. Hoekman and C. Özden, "The Euro-Mediterranean Partnership: Trade in Services as an Alternative to Migration", JCMS, Vol. 48 No. 4 (2010), (835) 851 (857).

127) $\operatorname{COM}(2010) 378,2-3 ; \operatorname{SEC}(2010) 884,6$ and 14.

128) $\operatorname{SEC}(2010) 884,21$.

129) It was also not identified as a problem by the stakeholders, $\operatorname{SEC}(2010) 884,98$.

130) Policy Plan on Legal Migration, $\operatorname{COM}(2005) 669,8$; $\operatorname{COM}(2010), 14$ (consideration 7 preamble); SEC(2010)884, 14 and 35. In comparison to the proposal on seasonal workers, the contribution to the development of the third country is not incorporated as a main objective (compare SEC(2010)887, p. 17 to $\operatorname{SEC}(2010) 884$, p. 20).

131) Although Article 3 (g) of the Blue Card Directive excludes ICT, the coordination between both directives is limited and the entry under this directive might facilitate the change in status under the latter directive and facilitate the acquirement of the long term resident status. 
the temporary nature that the "ICT should have to leave the EU territory, unless he/she is authorized to change status" ${ }^{132}$ Hence, the abovementioned remark that the nature of this migration is temporary in principle. Although the explanatory memorandum refers to the different rationale of the Directive on Family Reunification, being an instrument to foster integration of third country nationals who could become permanent residents, and this directive only setting up an attractive scheme, ${ }^{133}$ it cannot be denied that the attractiveness of the scheme also bears on the possibility of staying in the host country. It is assessed that taking into account the provisions on family reunification in the ICT directive (Article 15), ${ }^{134}$ there might be negative implications for circular migration. It is recognized that the transferee might not return home and acquire a permanent status, making the brain drain issue also a permanent reality. ${ }^{135}$ The two new proposals for directives might be an attempt to provide for a comprehensive immigration policy, but one can however, not avoid the impression that legal migration primarily remains a privilege of the highly qualified and skilled and that circularity remains an instrument of which the potential has yet to be found. ${ }^{136}$

The positive evolution of the alignment of certain conditions for legal migration, however never leading to a general right of entrance/admission, is overshadowed by the lack of an actual comprehensive and coherent approach. It seems that these directives have paid little attention to the needs of the developing countries, longing for more legal mobility channels for skilled and lower or unskilled migrants, and at the same time guaranteeing minimal negative effects. True legal commitments towards the mitigation of brain drain are weak ${ }^{137}$ and it remains to be seen whether and how the Member States will use the provided options. ${ }^{138}$ Moreover, the commitments towards ethical recruitment contain no obligations for the private sector employers and the Blue Card Directive is not applicable in the UK, Ireland and Denmark. In addition, guarantees of return and the issue of

\footnotetext{
132) $\operatorname{SEC}(2010) 884,22$.

133) $\operatorname{COM}(2010) 378,11$.

134) These are, except for the possible access to the labour market and accumulation of periods of residence, the same as in the Blue Card Directive.

135) SEC(2010), 31 and 40.

136) It appears that the access to the Union is easier for the highly qualified, only just referring to the number of options available in comparison to the low or unskilled, and this also appears to be the case for staying in the Union. Just one example: in Article 7 of the proposal on ICT it is possible not to renew the ICT permit (Member States may) or hold the host entity responsible and provide for penalties (Article 8) if the conditions of admission are not complied with. In the conditions of admission a proof of evidence of possible return to the country origin is required (Article 5). This implies that a return is expected of the ICT, but it does not necessarily lead to the impossibility to apply and receive a renewal. This in comparison to Article 12 of the proposal for seasonal workers, where the facilitation of re-entry is made strictly dependent on the obligation to return home.

137) S. Peers, "Legislative Update: EC Immigration and Asylum Law Attracting and Deterring Labour Migration: The Blue Card and Employers Sanctions Directives", European Journal of Migration and Law, Issue 11 (2009), pp. (387) 407 and 409 (426).

138) The transposition deadline for the Blue Card Directive being 19 June 2011.
} 
circularity are only taken into consideration where it is in the interest of the Member State. In sum, the desires of the Member States are addressed, but leave the needs of developing countries high and dry.

Considering the growing increase of remittances into and their impact on developing countries, this issue cannot be left out completely from the analysis. ${ }^{139}$ It can be argued that a certain degree of compensation for the loss of human capital could be found through the transfer of remittances by the third country nationals. ${ }^{140}$ However, as has been demonstrated, some provisions, mainly for the highly qualified, stimulate a more permanent form of migration. Hence, an increase of this kind of migration might result in a decrease of remittances. ${ }^{141}$ In addition, the possibility that these migrants will stay in the Union, can result into fiscal losses, as they will no longer pay taxes in the country of origin. ${ }^{142}$ It is suggested that in the case of actual temporary migration, this might generate significant remittance flows, as the link with the family members remains strong. ${ }^{143}$ However, this assumption will also depend on the migrants and their ties in the country of origin. In the case of younger migrants, it is possible that there are no or less extended families to take care of and the earnings will be used for own consumption or investment in the human capital of the migrant. ${ }^{144}$ The latter could be an asset for the country of origin in case of actual return. ${ }^{145}$ The transferred money will, in the first place, serve the family or community in the country of origin. Using the transferred money for consumption can have a positive impact on the local economies in the country of origin and addresses the most direct need of poverty alleviation at home. ${ }^{146}$ Also taking into account more long-term development issues, however, and the private nature of these assets, there is no guarantee that the remittances are used for more development oriented

\footnotetext{
139) For data on the level of worker remittances: the IMF keeps annual records on the amount of official worker remittance flows (Balance of Payments Statistics Yearbook). R.H. Adams, International Migration, Remittances and the Brain Drain. A Study of 24 Labor-Exporting Countries, The World Bank, Poverty Reduction and Economic Management Network, Poverty Reduction Group, June 2003, 36 pp.; S. Gupta, C. Pattillo and S. Wagh, Impact of Remittances on Poverty and Financial Development in Sub-Saharan Africa, IMF Working Paper, WP/07/38, February 2007, pp. 1-6 (43).

140) Gupta, Pattillo and Wagh, ibid., 43 pp.

141) Niessen, supra note 13, pp. (483) 496 (496); K. Mensah, M. Mackintosh and L. Henry, The Skills Drain' of Health Professionals from the Developing World: a Framework for Policy Formulation, Medact, February 2005, pp. 28-33 (50).

142) Y. Kerem Gümüs, "EU Blue Card Scheme: The Right Step in the Right Direction?”, European Journal of Migration and Law, Issue 12 (2010), pp. (435) 444 (453).

143) E.g. Commission Staff Working Document, Impact Assessment accompanying the Proposal for a Directive of the European Parliament and of the Council on the conditions of entry and residence of third-country nationals for the purpose of seasonal employment, SEC(2010)887, 13.07.2010, 24-25, $28-29$ and 39.

144) Hoekman and Özden, supra note 126, pp. (835) 845 (857).

145) Niessen, supra note 13, pp. (483) 496 (496).

146) Regarding the poverty reduction effect of remittances, see: Gupta, Pattillo and Wagh, supra note 139, 11-16 (43). Regarding the impact on financial development, see: Ibid., pp. 16-21 (43).
} 
investments, such as healthcare and education, nor is there a certainty that it will contribute to more sustainable economic management. The challenge is to open opportunities for those who wish to use (part of) the remittances for any form of investment supporting development. ${ }^{147}$

The correlation between legal migration and remittances, contributing to the development of the country of origin, will depend on a number of factors, such as the strength of the connection that remains with the country of origin, the knowledge regarding and the facilities available to transfer money to the country of origin, the use of the remittances by the recipient household, as well as the mechanisms in place to stimulate an input of these remittances into the development of the country of origin. There could be a role for remittances in reducing poverty and stimulating growth in the country of origin, but as is the case for legal migration, a lot remains to be done for development-enhancing remittances. ${ }^{148}$ Nevertheless, the possible positive contribution of remittances will (probably) not compensate fully for the loss of human capital in the developing country, especially in the case of the highly skilled, whose skills are much-needed in sectors like healthcare and the loss makes it harder to advance their innovative capital as a crucial driver of long-term growth. ${ }^{149}$

\subsection{Mobility Partnerships as the Tool for the Future?}

Mobility packages, as first suggested in 2006, were intended to become the instrument of the Global Approach. After the identification in December 2007 of

147) $\operatorname{COM(2005)390,~p.~} 20$.

148) Gupta, Pattillo and Wagh, supra note 139, 21-25 (43). Suggestions in the Communication on "Integrating Migration Issues in the European Union's relations with Third Countries", 03.12.2002, $\operatorname{COM}(2002) 703$, pp. 14-15: securing cheap, legal, secure and transparent mechanisms for transfer of remittances and by stimulating, the transfers, or a part, to be used to the benefit of the development of the developing country. For national examples, see: Ministerie van Buitenlandse Zaken, Voortgangsrapportage Internationale Migratie en Ontwikkeling 2008, Kamerbrief 26 januari 2010 (http://www.nieuwsbank.nl/inp/2010/01/26/R355.htm). The continued request for more development oriented measures: COM(2005)390, Annex 2 and 3, pp. 15-22; Communication on "Strengthening the Global Approach to Migration: Increasing coordination, coherence and synergies”, 08.09.2008, COM(2008)611, pp. 6-10; 2914th General Affairs Council meeting, Council Conclusions of the Global Approach to Migration and on the partnerships with countries of origin and transit, 8 December 2008, p. 5; Note from the Presidency to the General Affairs Council and European Council, "The Stockholm Programme - An open and secure Europe serving and protecting the citizens", 2 December 2009, p. 62. A concrete project so that remittances can better serve the development of the receiving countries is the set up of an African Remittances Institute. The preparatory phase started in 2010 and the aim is to facilitate better, more effective and safer remittances' transfer systems, which will fully take into account the specificities of the African countries. The first meeting of the steering committee in June 2010 marks the beginning of the implementation of the project, so it remains to be seen if this new project can serve as a development tool for poverty reduction. (Report of the 11th Meeting of the Joint AUC-EC Task Force, 20-21 October 2010, Addis Ababa, 43; http://www.afriqueavenir.org/en/2010/06/10/au-eu-launch-3-million-euromigration-project/).

149) Kerem Gümüs, supra note 142, pp. (435) 444 (453). 
countries eligible for pilot projects, in particular Moldova and Cape Verde, ${ }^{150}$ the established principles in the communication on circular migration and mobility partnerships were put into practice. The mobility partnership with Cape Verde seems to be a further illustration of a point already made. ${ }^{151}$ This partnership is politically framed into the Global Approach and legally within the existing cooperation frameworks, in particular the Cotonou agreement and the EU-Cape Verde Special Partnership. ${ }^{152}$ The choice for Cape Verde as pilot project seems logic, considering that the country belongs to the ACP Group of States and the EU-Africa Summit in December 2007 (infra), the Special Partnership, the evolution from a least developed country to a middle-income country. Yet it seems the emergence of West Africa as a major route for irregular migration, and their role in cooperation on illegal migration issues were decisive in making this choice.

The partnership, signed on 5 June $2008,{ }^{153}$ is based on a joint declaration, including the Community, Cape Verde and the five Member States ${ }^{154}$ willing to 'conclude' such a partnership. The voluntary character, with no legal framework and without a common approach can be considered as a first weakness, mainly at the disadvantage of the developing country. This was explained as being necessary in the view of flexibility and the need for differentiation anticipating the needs of the partner country. This approach on the legal nature is the reflection of prudence towards the division of competences concerning the internal as well as the external dimension of labour immigration policy. However, this 'soft law' basis can provide problems of coordination, leaving much in the hands of the Member States and offering no instrument to enforce promises made. ${ }^{155}$

The commitments of the parties seem unbalanced. The partnership in general provides for intensified cooperation and dialogue on the three thematic issues of the Global Approach. In the annex, some proposed activities were included. The offers of the Member States, concerning legal migration, contain issues on sufficient supply of information on legal migration, but also some actual efforts ${ }^{156}$ are made to facilitate legal circular migration for some categories of migrants and

\footnotetext{
150) Negotiations were started also with Senegal, but several obstructions have halted the process. See: M-H Chou, From Cotonou to Circular Migration: the EU, Senegal and the 'Agreement Duplicity, First draft paper for 'Migration: A World in Motion', Maastricht, the Netherlands, 18-20 February 2010.

151) Addendum "I/A" Item Note from the General Secretariat of the Council to the Permanent Representatives Committee/Council, "Joint Declaration on a Mobility Partnership between the European Union and the Republic of Cape Verde", 21 May 2008.

152) Communication "On the future of relations between the European Union and the Republic of Cape Verde", 24.09.2007, $\operatorname{COM(2007)641.~Adopted~in~the~2830the~General~Affairs~and~External~Relations~}$ Council meeting, General Affairs, Brussels, 19 November 2007.

153) Signature of a joint declaration on a mobility partnership between the European Union and Cape Verde, 10302/08 (Presse160), 5 June 2008.

154) Initially only Spain, France, Luxemburg and Portugal took part, later the Netherlands joined in 2008.

155) See note 28, CEPS Working Document, $\mathrm{N}^{\circ} 321$, October 2009, p. 29.

156) Joint Communiqué, II EU-Cape Verde Ministerial Troika Meeting, 9661/09 (Presse 122), 7 May 2009.
} 
to facilitate the exchange of students and teaching staff. The proposal for easier mobility through visa facilitation, almost the only Union undertaking, is still in the pipeline. ${ }^{157}$ The possibility to include measures to address the risk of brain drain, was translated e.g. into proposals for circular migration of highly qualified professionals and the support for Cape Verdean national health systems. These are however mainly proposals waiting to be implemented and for a large part dependent on the good will of the Member States. The offer of legal migration opportunities will thus depend on the (labour market) needs of the individual Member State and present little or no guarantees for new mobility opportunities and contributions on the development front. The issues on illegal migration and asylum seem to be formulated in a more compulsory manner for Cape Verde. The commitments on illegal migration and effective mechanism for readmission, being eligibility criteria, explain partly the choice for Cape Verde, as the commitment towards readmission is already present in Article 13 of the Cotonou Convention. ${ }^{158}$ The implementation of commitments made by the Member States and the Union is made conditional on Cape Verde entering into the binding commitments on illegal migration, in other words possible mobility as a "reward" for compliance. ${ }^{159}$

The mobility partnership does not fully comply with the EU commitment towards a truly comprehensive and balanced migration policy and the idea of 'partnership' can be equally doubted. The mobility partnership seems, taking into account the lack of an actual balance in legal commitments and a true common approach, just a first step and an opportunity that comes with many challenges.

Despite the fact that it was still too early to analyze the mobility partnership with Cape Verde, the Commission further pushed forward the mobility partnerships as the most promising tool for the Global Approach. ${ }^{160}$ The same line of reasoning, as being non-binding in nature and providing a framework for bilateral agreements between the third country and a Member State, was kept. Hence, the possibility that they actually evolve to more compulsory commitments for both parties does not seem realistic. The identification of future partners was suggested to be based more on strategic interest in the long term, but the country's capacity to implement and of course its willingness to cooperate on the illegal migration front, as well as the interests of the Member States, were kept as

\footnotetext{
157) 2009/JLS/036 Draft Council Decision on the signature and conclusion of the Agreement between the European Community and Cape Verde on the facilitation of issuance of short-stay visas: Subject to a successful outcome of the negotiations, to propose to the Council to conclude and sign the agreement in accordance with Article 218 TFEU.

158) Negotiations have started on both a visa facilitation agreement and a readmission agreement (EU-Cape Verde Political Dialogue Meeting at Ministerial level, 5796/10 (Presse10), 26 January 2010.

159) Triandafyllidou, supra note 44.

160) Commission Staff Working Document - Mobility Partnerships as a tool the Global Approach to Migration, 21.09.2009, SEC(2009)1240.
} 
prerequisites. ${ }^{161}$ The actual comprehensive and balanced approach of these partnerships will most likely depend on the willingness and needs of the Member States and the power of the third country in question. The lack of a common, Union approach might also undermine the importance of coherence and coordination. Therefore, these mobility partnerships do not provide for much legal certainty and guarantees for an equality between legal migration, illegal migration and the positive migration-development nexus and between the partners. The challenge for the future is thus avoiding the evolution into an instrument in the hands of the Member States only in their national interests. ${ }^{162}$

\section{The EU-ACP Relationship: A Model for Change or More of the Same?}

It is wondered whether and how these evolutions have found their place in this specific relationship, considering that Sub-Saharan Africa as well as the Caribbean and Pacific regions are extremely vulnerable to immigration and the consequences of the exodus of skilled workers. Unfortunately, the EPAs are a mere expression of the fact that a comprehensive migration-development-trade policy is also lacking here.

\subsection{Migration Issues in the General EU-ACP Framework}

The relationship with the African continent, and later the ACP, has always been at the forefront of the EU external relations. This relationship has been characterized by the focus on trade (in goods) and development cooperation. As the external dimension on migration emerged in general policy documents in parallel, it has surfaced in the relationship with the ACP. This is somewhat logic considering the fact that the ACP, in particular the African continent, has been identified quite early as a priority area.

The joint declaration in Lomé II $^{163}$ only provided for measures for legally residing workers (Annex XV). In Lomé III ${ }^{164}$ an additional declaration was annexed to enhance the rights for legally migrating workers (Annex IX). The admission for students was left to the bilateral framework. The Annex did provide for possible support, both for training of migrating workers who return and the education of ACP students aimed at vocational integration in their country of origin. It was furthermore added that the ACP countries should take the necessary measures

161) COM(2008)611; SEC(2009)1240; Council Conclusions on Mobility Partnerships as a tool of the Global Approach to Migration, 2979th Justice and Home Affairs Council meeting, 30 November 2009.

162) See note 28, CEPS Working Document, $\mathrm{N}^{\circ} 321$, October 2009, p. 32.

163) OJ L 347/1 of 22.12.1980.

164) OJ L $86 / 1$ of 31.03 .1986$. 
with regard to illegal migration. Lomé IV ${ }^{165}$ only completes the picture by adding non discrimination for workers, students and other foreign nationals (Article 5, paragraph 4) into the main text of the Convention. The provisions are thus, not illogic considering the timeframe, scarce with regard to immigration and contained no provisions on mobility or admission.

The further development in the Cotonou Convention ${ }^{166}$ and the Cairo Declaration ${ }^{167}$ fits perfectly into the standard policy guidelines. The partnership agreement incorporates migration in the political dialogue (Article 8, paragraph 3). Moreover a separate migration clause was included in Article 13. This includes the specific in-depth dialogue concerning migration and consolidates the former declarations on non discrimination, on tackling the root causes of migration, on support for training geared at vocational integration of ACP nationals in their countries of origin and on cooperation to facilitate access of ACP students to education. Furthermore, specific paragraphs were added to include illegal migration issues into the political dialogue (paragraph 5) and, in line with attention for illegal migration and the later Seville Council, ${ }^{168}$ a readmission clause ${ }^{169}$ was provided for. ${ }^{170}$ The need for action to reverse brain drain, called for in the Cairo Plan of Action, was reflected in a specific brain drain clause in the technical cooperation framework (Article 80). This is however limited to possible support of the Community, upon ACP request, to facilitate the return of qualified ACP nationals through re-installation incentives. The development-migration connection is present, but still based on an approach looking at the problems of poor development in the country of origin ${ }^{171}$ and illegal migration, and was not taken on from the possible contribution of migration to development point of view. Despite the shift, at least theoretically, to a more balanced and comprehensive approach, this was not addressed in the first revision of the Cotonou Convention. ${ }^{172}$ The concerns of the ACP regarding evolutions in the EU vision on mobility, brain drain and the link with illegal immigration, increased as expressed in the Nadi Declaration ${ }^{173}$ and they requested for better cooperation.

\footnotetext{
165) OJ L 229/1 of 17.08.1991and OJ L 156/1 of 29.05.1998.

166) OJ L $317 / 3$ of 15.12 .2000$.

167) Africa-EU Summit, under the Aegis of OAU and the EU, Cairo, 3/4 April 2000, Conseil/00/901 and 107/4/00 REV 4.

168) Presidency Conclusions, Seville European Council, 20 and 21 June 2002.

169) The Parties agree to accept return and readmission upon request and without further formalities. It further provides for negotiations on readmission agreements for implementation in practice.

170) Article 13 was considered to be a model for negotiation in future agreements with third countries (COM(2002)703).

171) The incorporation in Country and Regional Strategy papers was also mainly addressed from the impact of development on migration and not of the possible stimulus migration might provide for development.

172) OJ L 209/26 of 11.08.2005.

173) 3rd Summit of ACP Heads of State and Government, Denarau, Nadi-Fiji Islands , 18/19 June 2002, Nadi Declaration, ACP Solidarity in a Globalised World.
} 
The increased attention for migration was also reflected by initiatives on the 'internal' African front, with an important role for the African Union (AU) and the New Partnership for Africa's Development (NEPAD). This attention for migration consists of several measures, such as the 1991 Abuja Treaty striving for free movement of persons in the framework of an African Economic Community, the NEPAD Human Resources Development Programme, the NEPAD Health Strategy, ${ }^{174}$ the Ouagadougou Declaration on employment and poverty alleviation, the Nyerere programme for students. A non binding migration policy framework for Africa was adopted in 2006 in the framework of the AU, serving as a guide for national migration policies. ${ }^{175}$ From these documents, it appears that migration is mainly addressed from the possible positive effects on migration, while mitigating the negative. Regardless of the fact that an important responsibility belongs to the developing countries themselves, the set goals can however not be reached without cooperation and commitments from both parties.

Although the 2005 EU Strategy for Africa ${ }^{176}$ does mention the possible positive contribution of migration for development, the focus still seemed to be on tackling illegal migration and migration or exchange of students (Erasmus Mundus), teachers and researchers and the root causes of migration. Still, the general legal migration issue and brain drain problem are only scarcely touched upon. ${ }^{177}$ Slowly, but surely, the importance of Africa in an enhanced dialogue and cooperation on all fronts was endorsed ${ }^{178}$ and eventually consolidated into the Global Approach. The consolidation and strengthening of the dialogue was further pursued, which resulted in the Rabat conference at regional level. The Euro-African Partnership for Migration and Development concentrated on managing specific migration flows along the Western African route. The better use of legal migration and movement of people were enumerated as relevant issues. The Tripoli Declaration (2006) was the first joint approach on migration and development between the EU and the entire African continent. It is a political commitment on both sides to cooperate on the overall migration front, including human resources, brain drain and regular migration opportunities, referring e.g. to circular migration and recruitment policies. The Rabat follow up in Paris (2008) fully includes the evolution towards the Global Approach and confirms made political commitments. It is clear that since 2006 migration has evolved to one of the key topics

\footnotetext{
174) http://www.nepad.org/2005/files/documents/115.pdf.

175) Executive Council, Ninth ordinary session, 25-29 June 2006, Banjul, the Gambia, "The Migration Policy Framework for Africa".

176) Communication on an "EU Strategy for Africa: Towards a Euro-African pact to accelerate Africa's development", 12.10.2005, COM(2005)89.

177) "EU Strategy: The EU and Africa: Towards a Strategic Partnership" (doc. 15702/1/05) endorsed at the European Council meeting, December 15/16 December 2005.

178) COM(2002)703; Council conclusions on Migration and External Relations, 2691st External Relations Council meeting, 21 November 2005.
} 
in the EU-Africa dialogue. ${ }^{179}$ This was in conformity with the general evolutions encompassing all three aspects of the Global Approach, but also demonstrated the need for concrete action and the resistance towards mobility for all migrant categories. ${ }^{180}$ The Commission explicitly stated that the priorities had been set, but the real test, in particular for Africa, was still to come. ${ }^{181}$

The integration of migration into dialogue at continental, regional, and bilateral level could only lead to migration being one of the priority areas in the Joint Africa-EU Strategy (JAES) established at the 2nd EU-Africa Summit in Lisbon (2007). ${ }^{182}$ Migration and development was included into the strategy aimed at accelerating progress towards the MDG. The 7th Partnership on Migration, Development and Employment in the First Action Plan (2008-2010) is considered to be a consolidation of the longer term migration and development agenda taken forward with Africa to date, ${ }^{183}$ identifying amongst others the implementation of the Tripoli Declaration as a priority. It is not surprising that the mobility side is focusing on circular migration. In the promotion of dialogue and cooperation regarding visa to facilitate mobility, the officials involved on a regular basis in the EU-Africa partnership, are identified as a priority area and thus appear to limit the options for a broader visa facilitation. Other measures identified are enhancing education and vocational training, as well as enhancing the implementation of measures to tackle shortages of health workers in developing countries, ${ }^{184}$ promotion of ethical recruitment and creating incentives for the retention and return of key qualified personnel, only repeating general calls and the commitment of Article 80 Cotonou. From a general analysis, it appears that the occasion to counterbalance the desire of the EU on stronger commitments of Africa concerning illegal migration, with equally strong commitments on more legal migration options and actual brain drain measures, was not grasped. In addition, only about half of the Member States and about 8 ACP countries are engaged in the 7th Partnership. ${ }^{185}$

The tools of the Global Approach were applied intensively. This concerns, e.g. the EU migration missions to guarantee and support the integration of migration

\footnotetext{
179) T. van Criekinge, "The Integration of Migration Issues in EPAs", in G. Faber and J. Orbie, Beyond Market Access for Economic Development. EU-Africa Relations in Transition, London: Routledge 2009, pp. (173) 180-183.

180) E.g. Note from Council to European Council, "The EU and Africa: Towards a Strategic Partnership. The Way Forward and Key Achievements in 2006", 11 December 2006; Communication "From Cairo to Lisbon. The EU-Africa Strategic Partnership", 27 June 2007, COM(2007) 357.

181) $\operatorname{COM}(2007) 1632$.

182) Commission/Council Secretariat Joint Paper, "Beyond Lisbon. Making the EU-Africa Strategic Partnership work", 27.06.2007, SEC(2007) 856; Lisbon Declaration - EU Africa Summit, Lisbon, 8/9 December 2007, 16343/07 (Presse 290).

183) $\operatorname{COM}(2007) 780$.

184) Also included in the Partnership on the MDG.

185) Joint Progress report in the implementation of the Africa-EU Joint Strategy and its first Action Plan; http://europafrica.net/jointstrategy/migration/.
} 
in the political dialogue, the development cooperation platforms, the establishment of migration management centres, the incorporation of migration profiles into the Country Strategy Papers, a mobility partnership, the support for cooperation through the AENEAS Programme and later the thematic programme 'Cooperation with third countries in the areas of migration and asylum', the support through the EDF, ${ }^{186}$ Erasmus Mundus, Edulink, the Centre for Migration Information and Management (CIGEM) in Mali, etc. The latter, as well as a lot of the other measures, was officially established to not only curb illegal migration, but also to help those who want to migrate legally. Critics however suggest this is nothing more than a watchdog for the EU. ${ }^{187}$ The actual result of these initiatives is hard to measure and some of them seem to answer the EU concerns rather than the positive migration contribution for development. It cannot be denied that substantial efforts and some achievements, e.g. intensification of the dialogue on migration, have been made during the past few years. Nevertheless, the follow up of the Lisbon Summit demonstrates that the focus seems to be on these general measures, in particular for data gathering and analysis, the importance of remittances and cooperation on illegal migration, offering little concrete implementation measures for a broader legal mobility framework nor addressing the brain drain issue. ${ }^{188}$ The adopted roadmap ${ }^{189}$ and midterm review, ${ }^{190}$ referring only to the mobility partnership with Cape Verde with regard to mobility, proves the limitations of the Union binding offers on legal migration and brain drain and the fact that it remains in the hands, and thus also the good will, of the Member States for actual measures. This increases the risk to be used only in their own interest and also brings forward the question of a long-term common 'development' vision on circular migration. ${ }^{191}$

The proposals of the Commission on how to consolidate and further evolve the Strategic Partnership ${ }^{192}$ (JAES), preceding the 3rd EU-Africa Summit, as well as

\footnotetext{
186) Although critics have pointed out the aid development was too much conditioned upon the fulfillment of commitments on illegal migration.

187) "EU opens migration centre in Mali, 'Outpost watchtower of Fortress Europe”", http://www. mo.be.

188) Communication from the Commission to the Council and the European Parliament, "One year after Lisbon: The Africa-EU Partnership at Work", 17.10.2008, COM(2008)617 and SEC(2008)2603; Joint Communiqué 11th Africa-EU Ministerial Troika Meeting, Addis Ababa, 20/11 November 2008, 16189/08(Presse 341). Joint Progress report in the implementation of the Africa-EU Joint Strategy and its first Action Plan.

189) 12th Africa-EU Ministerial Troika meeting, Luxembourg, 28 April 2009, 7472/09(Presse 60), Roadmap October 2009.

190) 13th Africa-EU Ministerial Troika meeting, Addis Ababa, 14 October 2009, 14504/09(Presse 292). Assessment report (9 Oct. 2009 FINAL, as endorsed by JFT).

191) IOM - Unitar, "Africa-EU 7th Partnership on Migration, Mobility and Employment: Moving forward involving Non-State Actors", 4 June 2009, Brussels.

192) Communication on "The consolidation of EU Africa relations. 1.5 Billion people, 80 countries, two continents, one future", 10.11.2010, $\operatorname{COM}(2010) 634$, 5-6. Reference is made, in the framework of inclusive growth, to the need for high-employment economies. In that same framework also cooperation on migration and mobility is included, again referring to circular migration as means for legal migration
} 
the list of achievements on the eight thematic partnerships, ${ }^{193}$ are poor in regard to legal migration and the brain drain issue. It is clear that migration is a difficult and highly sensitive subject that needs further discussion. Hence, it is no surprise that in the overreaching theme of "Growth, Job Creation and Investment" of the 3rd Summit, migration was a hot topic. ${ }^{194}$ The overreaching theme was broken down into sub-themes, amongst which 'Migration, Mobility and Job Creation'. The note in the overview of the Partnership on Migration Mobility and Employment in the 2nd Action Plan (2011-2013) of the JAES, on the intensification of dialogue and co-operation, the uneven scattered results, the reliance on political interests, difficulties regarding institutional capacities as well as competence issues regarding migration and employment policies, confirm the difficulties surrounding the migration debate. ${ }^{195}$ Valuable initiatives have been taken and the introductory note of the 2 nd Action Plan stresses the need to facilitate mobility and better manage legal migration and enhance the development impact of migration, thus confirming the commitment of making migration and mobility work for development. ${ }^{196}$ This was translated in the general objective of the Partnership through the inclusion of topics such as 'diasporas, remittances, brain drain, regular migration, including circular migration, mobility and visa issues' into the dialogue. ${ }^{197}$ However, the list of specific initiatives and activities is disappointing on this issue. ${ }^{198}$ Amongst others, the facilitation of dialogue and the creation of the ACP Observatory on Migration was included. The aim is to collect reliable and harmonized data on migration to be able to establish better policies to enhance

\footnotetext{
"in direct connection with the labour market requirements and employment opportunities in both continents". The aim of reducing illegal migration is also included. No mention is made on the brain drain problem, nor an explicit referral to attain to objective of making migration work for development was incorporated.

193) Key deliverables of the Joint Africa-EU Strategy, 01/06/2010, 6; 3rd Africa EU-Summit 29/30 November, Tripoli, 24 November 2010, MEMO/10/604, 15-16. In general containing an enumeration of the abovementioned tools of the Global Approach. In the declaration following the meeting of the parliamentarians representing the Pan-African and European Parliaments reference is only made to addressing the root causes of (illegal) migration and, through creating prosperity and employment, and the commitment to limiting the harmful effects of brain drain. In addition, not a word creating channels for legal migration that also foster the development of the country of origin. (EP-PAP Parliamentary PreSummit, Declaration for the Third Africa-Europe Summit, Tripoli, 27 November 2010.

194) 3rd Africa EU-Summit: Team up for more "Investment, Economic Growth and Job Creation", 25 November 2010, IP/10/1605.

195) Joint Africa EU Strategy, Action Plan 2011-2013, Partnership on Migration, Mobility and Employment, p. 61.

196) Joint Africa EU Strategy, Action Plan 2011-2013, Introductory Note, p. 6.

197) Joint Africa EU Strategy, Action Plan 2011-2013,Partnership on Migration, Mobility and Employment, p. 62.

198) Maybe the specific mention of the mobility of students and academics, in the introductory note, as well as the reference to facilitate mobility for commercial, professional and study reasons, was already a signal that concrete initiatives on mobility for broader categories of migrants would be limited.
} 
the migration contribution to development. ${ }^{199}$ It remains to be seen if this objective will be delivered and if such a data collection is not only to be used to the benefit of the Union. It appears that creating the right conditions in Africa for more and better jobs was stressed, thereby enhancing employment at home ${ }^{200}$ and contributing to development, but this was also seen as a manner to tackle some of the causes of (illegal) migration, and again the issue of illegal and irregular migration was emphasized. ${ }^{201}$ The question of mobility and (additional) legal migration channels was only scarcely touched upon through the inclusion in the dialogue and barely any mention was made of the brain drain problem. ${ }^{202}$ The inclusion into the dialogue of regular migration and brain drain is a recognition of the importance of these issues, but this inclusions and the absence of concrete initiatives are also an indication that a lot remains to be done.

It was only later that the Caribbean region emerged into the migration debate. In the EU Caribbean Partnership ${ }^{203}$ unemployment, migration and brain drain are identified as challenges. However in reversing them to opportunities nothing points out the possibilities of legal migration and concrete measures for the brain drain problem. Furthermore, mentioning the support for the health systems and education and the role of Cuba in counterbalancing the brain drain problem, only the problem of an active recruitment policy of the US was included. The first steps towards the commitment in the Lima declaration of May $2008^{204}$ for a structured and comprehensive dialogue on migration, was taken in June 2009 through the launching of a Structured Dialogue on Migration. ${ }^{205}$ The dialogue should include the link between migration and development and regular migration. The integration of migration in this relation is still in its infancy. This is clearly shown in the Commission's communication ${ }^{206}$ in preparation for the EU-LAC Summit and the Madrid Declaration ${ }^{207}$ and the Madrid Action Plan

\footnotetext{
199) Joint Africa EU Strategy, Action Plan 2011-2013, Partnership on Migration, Mobility and Employment, 63-65.

200) Tripoli Declaration, 3rd Africa EU Summit, 29/30 November 2010; Joint Africa EU Strategy, Action Plan 2011-2013, Introductory Note, 6 (point 24).

201) Joint Africa EU Strategy, Action Plan 2011-2013, Introductory Note, 6.

202) Only in the framework of the overall objective it was stated that "in direct relation to strategies on employment, mobility and the harnessing of brain drain the parties will extend their dialogue to the area of higher education".

203) Communication on "An EU-Caribbean Partnership for Growth Stability and Development", 02.03.2006, $\operatorname{COM}(2006) 86$.

204) Latin America and Caribbean-European Union Summit, Lima, May 16 2008, Lima declaration "Addressing our Peoples' Priorities together".

205) Launch of the EU-LAC Structured Dialogue on Migration, 30 June 2009 11577/09 (Presse 201) based on the joint document "Basis for Structuring the EU-LAC Dialogue on Migration".

206) Communication on "The European Union and Latin America: Global Players in Partnership", 30.09.2009, $\operatorname{COM}(2009) 495$.

207) European Union - Latin America and Caribbean Summit, Madrid Declaration "Towards a new stage
} 
(2010-2012) ${ }^{208}$ following this summit. These documents confirm the clear emphasis and increased importance of the migration issues, but remain limited in repeating the importance of the Structured Dialogue on Migration as a building block and the general view on the need for a strong dialogue and co-operation in line with the Global Approach to Migration. The Action Plan includes the need to strengthen the positive link between migration and development, but contains nothing on measures to enhance mobility or to address the brain drain problem. The inclusion of the migration issues seems to be more dictated (again) by the fear of growing migration flows from these areas than development concerns regarding the possible positive contribution of migration. The specific EU-CARIFORUM Summit ${ }^{209}$ and the outline for a new Partnership Strategy ${ }^{210}$ are obviously determined by the circumstances, focusing on climate change, natural disasters and in particular Haiti. Migration does not appear in the identified priorities. Only time will tell whether a balanced and comprehensive approach can be reached.

Although the importance of a broad political dialogue is also included in the relation with the Pacific region, ${ }^{211}$ no specific mention is made on migration. This is not that surprising considering the geographical distance and the importance of other common interests.

The lacunae in Article 13 Cotonou, too much attention for illegal migration and a lack of implementation of general evolutions, such as attention for mobility and migration as a contribution for development, called for a revision and operationalization of the Article. ${ }^{212}$ The negotiating directives ${ }^{213}$ seemed promising in bringing it in line with the Global Approach, however caution towards overstressing illegal migration was advised. The problems surrounding migration issues are illustrated by the fact that the main text of the revised version does not contain these new elements on migration. ${ }^{214}$ The criticism ${ }^{215}$ for too much attention on illegal migration, without any guarantee that the ACP countries may fulfil

\footnotetext{
in the bi-regional partnership: innovation and technology for sustainable development and social inclusion”, 18 May 2010, 9931/10 (Presse 131).

208) EU-Lac Summit, Madrid Action Plan (2010-2012) "Towards a new stage in the bi-regional partnership: innovation and technology for sustainable development and social inclusion”, 18 May 2010.

209) IV EU-CARIFORUM Summit Joint Communiqué, 17 May 2010, 9831/10 (Presse 128).

210) Outline for a Joint Caribbean-EU Partnership Strategy, 17 May 2010, 9701/10 (Presse 118).

211) Communication form the Commission tot the Council, the European Parliament and the European Economic and Social Committee, "EU relations with the Pacific Islands. A strategy for a strengthened partnership", 29.05.2006, $\operatorname{COM}(2006) 248$.

212) E. Koeb and H. Hohmeister, "The revision of Article 13 on Migration of the Cotonou Partnership Agreement. What's at stake for the ACP?", ECDPM, December 2009.

213) Council of the European Union N 6383/09, ACP 45 PTOM 13, Brussels, 13 February 2009.

214) Second revision of the Cotonou Agreement - Agreed consolidated text 11 March 2010 (http://ec. europa.eu/development/icenter/repository/second_revision_cotonou_agreement_20100311.pdf), signed on 19 March 2010. Second revision of the Cotonou Agreement signed, Ouagadougou, 22 June 2010, 11329/10 (Presse 187). OJ L 297/3 of 04.11.2010.

215) Koeb and Hohmeister, supra note 212; http://migreurop.org/Article1627.html?lang=en.
} 
their obligations and are able to guarantee the respect for fundamental rights and freedoms, as is necessary under a readmission commitment, remain relevant considering the suggestions made on the part of the EU. ${ }^{216}$ Besides, the suggested inclusion of the principle of circular migration as such was not welcomed, as bilateral measures indicate that these are instruments in the interest of the Member States to tackle illegal migration and stressed on the return treating the migrant worker as disposables. The EU and the ACP only agreed in a joint declaration to continue and strengthen the dialogue and cooperation on migration and report on the progress made to the next ACP-EU Council (June 2011). ${ }^{217}$ The identification of the remaining points of disagreement, in particular the readmission clause and the need to assure that Official Development Assistance is not made dependent on the signing of readmission agreements, demonstrates the concerns for the instruments to be used for conducting "restrictive and security-driven immigration policies". ${ }^{218}$ It is hoped that the foreseen commitment to strengthen cooperation in the area of migration and negotiations for an appendix ${ }^{219}$ to the convention will answer the quest for a comprehensive approach encompassing a true 'Migration and Development' cooperation, concrete opportunities for increased mobility also for low skilled, strong and binding provisions also on legal migration, mitigating brain drain and making migration a truly free choice. ${ }^{220}$

\subsection{Trade in Services at the Service of Development?}

Although the EPA provisions on trade in services provide for a temporary right to perform a given economic activity and make movement across borders easier, it does not cover visa or conditions on entry, stay and work. ${ }^{221}$ Nonetheless, it has a great impact on whether or not these legal commitments are coherent with the contribution of legal migration to development and at the same time mitigate brain drain, thus turning trade into a highly sensitive political migration issue.

\footnotetext{
216) Suggested changes on the part of the EU even make the commitments on the part of the ACP more arduous, e.g. making the readmission clause self-executing and increasing the burden of proof and time in establishing the country of origin.

217) The joint declaration (II) on migration and development calls for a comprehensive and balanced approach, based on three pillars: Migration and Development, including brain drain and remittances; legal migration, including mobility movement of skills and services and illegal migration. The Parties will work out the details of the enhanced cooperation on migration and commit to a timely completion of the dialogue. (OJ L 287/48 of 04.11.2010)

218) Concord Cotonou Wokring Group, briefing Paper, "The revision of the Cotonou Partnership Agreement", ACP-EU Parliamentary Assembly, 19the Session, Tenerife, 27 March-1 April 2010.

219) Background note on the Second Revision of the Cotonou Agreement, Brussels, 19 March 2010.

220) Concord Cotonou Working Group, briefing Paper, "The revision of the Cotonou Partnership Agreement", February 2010.

221) Service providers were generally not considered as immigrants. On the gradual weakening of the services and migration distinction, see: V. HATZOPOULOS, "Liberalizing Trade in Services: Creating new Migrant Opportunities", Research Papers in Law (Cahiers juridiques), No 1/010 (www.coleurope.eu), 29.
} 
The provisions on services with a possible impact on these issues are those that produce a certain movement of persons, being mode 3 GATS (commercial presence) or establishment and in particular mode 4 GATS (temporary presence of natural persons), the one often implying also the other. It is analyzed if the feasible solution that mode 4 GATS might offer for development, as suggested in particular by developing countries, ${ }^{222}$ is implemented in the EPA in the best optimal way. 223

In Lomé IV (Article 185), the importance of the service sector and the goal of gradual liberalization was recognized, but the matter was left to future cooperation and negotiations. The commitment in the Cotonou Convention towards the WTO regarding trade in goods was not so firm for trade in services and only anticipated on the future extension of the EPAs to encompass liberalization of services (Article 41, paragraph 4). ${ }^{224}$ The majority of the EPAs are only stepping stone agreements concluded with one or more countries and including only trade in goods. The one with Cameroon ${ }^{225}$ only refers to commitments under the GATS, the Cotonou Framework and a deadline already passed, for extending the scope and liberalization of establishment and trade in services (Article 54 and 55). This is also the case in the one with the SADC EPA States (Article 13 iuncto 67). ${ }^{226}$ The Ivory Coast $\mathrm{EPA}^{227}$ (Article 44) was even more general in referring to Cotonou, the WTO and trade in services, without reference to the GATS, liberalization and a deadline. The difficult balance in trade in services at the service of development also came to the fore in the drafting of the Pacific EPA, including provisions on skilled and semi-skilled, but with no reference to low skilled service workers. Eventually, the draft was not accepted and the commitments in

\footnotetext{
222) X., "Negotiating Services Free Trade Agreements (FTA's) With the European Union: Some Issues for Developing Countries to Consider", South Centre (www.southcentre.org), Geneva, June 2009, 7-8. If mode 4, through binding commitments in agreements, is used in a way that would benefit both countries, it would be a major improvement compared to the mobility partnerships which are voluntary. Hoekman and Özden, supra note 126, pp. (835) 852 (857).

223) In addition, account needs to be taken of the fact that mode 4 GATS is also subject to the negotiations in the Doha Round ("Understanding GATS Mode 4: Return Migration of Temporary Workers", Briefing Paper, Quaker United Nations Office, Geneva, August 2007-October 2007, Volume 26 Number 4).

224) This was not altered under the second revision of the Convention.

225) Interim Agreement with a view to an Economic Partnership Agreement between the European Community and its Member States, of the on part, and the Central African Party, of the other Part, OJ L 57/1 of 28 February 2009. The EPA endorses the 7th Partnership by implementing the employment growth as a general objective (Article $2(\mathrm{~h})$ ).

226) Interim Agreement with a view to an Economic Partnership Agreement between the European Community and its Member States, of the one part, and the SADC EPA States (Botswana, Lesotho, Swaziland, Namibia), of the other part, OJ L $319 / 3$ of 4 December 2009. The preamble only includes the wish to create new opportunities for employment.

227) Stepping Stone Economic Partnership Agreement between Côte d'Ivoire, of the one part, and the European Community and its Member States, of the other part, OJ L 59/1 of 3 March 2009.
} 
Article 69, paragraph 1 of the interim agreement ${ }^{228}$ only refer to ongoing negotiations for a comprehensive EPA. ${ }^{229}$

A comprehensive and global EPA was only concluded with the CARIFORUM states. ${ }^{230}$ It is clear from the outset, the provisions on commercial presence (Articles 65-74) and on temporary presence of natural persons for business purposes (Articles 80-84) and from the list with specific commitments (Annex IV) that these are only aimed at (highly) skilled service providers. ${ }^{231}$ Article 60 (5) explicitly excludes natural persons seeking access to the employment market. The list with commitments on commercial presence of business services includes for example medical and dental services, midwives, nurses etc. The provisions on temporary presence illustrate this even more clearly, being limited to key personnel, graduated trainees, business services sellers, short term visitors for business purposes, independent professionals and contractual service suppliers. The latter two are constraint through a limited enumeration of categories (Article 83) and the majority requiring a university degree or professional qualifications. It is not overtly clear whether these categories also fall under the abovementioned (supra, section 3.1.) visa waiver agreements. In principle, it excludes persons who travel for the purpose of a paid activity from the waiver exemption, but the joint declaration clarifies these persons should ${ }^{232}$ not cover e.g., business persons and intracorporate trainees. This would seem logic, leading to an actual facilitation of mobility.

These provisions illustrate the position taken by the developed countries rejecting the use of mode 4 GATS as an option also for lower and unskilled migrants, as long as developing countries can not sufficiently guarantee their return. ${ }^{233}$

The access of those service providers is not without reservations and is, since it regards services, temporary anyhow. Article 60, paragraph 5 furthermore states the provisions are not applicable for measures regarding citizenship, residence and employment on a permanent basis. ${ }^{234}$ The provisions on the presence of natural

\footnotetext{
228) Interim Partnership Agreement between the European Community, of the one part, and the Pacific States (Papua New Guinea and the Fiji Islands), of the other part, OJ L 272/2 of 16 October 2009.

229) J. Kelsey, "Going Nowhere in a Hurry? The Pacific's EPA Negotiations with the European Union", VUWLawRW 8, 2007 (38,1); Van Criekinge, supra note 179, p. (173) 186.

230) Economic Partnership Agreement between the CARIFORUM States, of the one part, and the European Community and its Member States, of the other part, OJ L 289/I/1 of 30 October 2008.

231) Although it must be mentioned the commitments on the part of the EU are considered to be more liberal than the commitments under the GATS.

232) The Dutch and German translation are formulated more in a "do not cover" way.

233) X., "Negotiating Services Free Trade Agreements (FTA's) With the European Union: Some Issues for Developing Countries to Consider", South Centre (www.southcentre.org), Geneva, June 2009, 7-8; Van Criekinge, supra note 179, p. (173) 179.

234) This in conformity with the Annex to the GATS on the Movement of Natural Persons Supplying Services under the Agreement, where the application is explicitly excluded for natural persons seeking access to the employment market of a Member and for measures regarding citizenship, residence and employment on a permanent basis.
} 
persons contain limited timeframes, e.g. one year for graduate trainees (Article 81). Although being temporary in nature the third country national might, e.g. after his contracts with his employer in an ACP country ends, seek to apply the Blue Card directive and consequently, if in conformity with the criteria, the status is granted $^{235}$ satisfy the conditions for a long term resident status more easily. Although the Blue Card directive does not apply to persons who enter under commitments in an international agreement facilitating entry and temporary stay of trade or investment-related natural persons (Article $3(\mathrm{~g})$ ), there seems to be no obstacle for applying the directive after the entry based on such a provision. There appears to be, besides the made reservations of some Member States and possible e.g. qualification requirements, no hindrance (connected to development considerations) for a service provider from an ACP country to establish a practice here. It must however be noticed that for medical services, midwives, nurses etc., the possibilities to provide services are (seriously) constrained through national reservations and Member States who are unbound (meaning no commitment is made to liberalize). ${ }^{236}$ The reservations are especially present under mode $4^{237}$ and are clearly not motivated by pure altruism, but are mainly based on the economic needs test, recognition, nationality or residence requirements ${ }^{238}$ as remaining barriers to trade. ${ }^{239}$ Nonetheless, these aspects of the service provisions might aggravate the brain drain problem since there are no guarantees to ensure temporariness or circularity. ${ }^{240}$ As already clarified, the Blue Card directive contains weak commitments, nor does the EPA provide for guarantees to mitigate brain drain, although binding commitments could have easily been included, being a mixed agreement. This might have provided a dignified alternative for the absence of a Union Code of Conduct. The contribution to development and in particular the mitigation of the negative consequences, will have to be supported through other measures, such as the initiatives on the cooperation of diasporas or bilateral agreements/measures by individual Member States. Nevertheless, these often offer little legal certainty.

The facilitation to provide services might be an added value for the country of origin on other fronts, but it seems to be mainly directed to the (highly) skilled,

\footnotetext{
235) For example, a requirement might be she/he is at least legally present in a Member State (see Article 10 Directive 2009/50/EC).

236) Hoekman and Özden, supra note 126, pp. (835) 852 (857), indicates that 16 Member States will apply an economic needs test in case of medical and dental service, 21 Member States did for veterinary services and 22 apply a test regarding nursing services.

237) P. Sauve and N. Ward, Services and investment in the EC-CARIFORUM Economic Partnership Agreement: Innovation in rule-design and implications for Africa.

238) Pending an agreement on mutual recognition the requirements of the territory where the service is supplied apply (Article 85) (and as also provided for in Article VII GATS). The second review of Cotonou Convention should also accelerate work on the mutual recognition of higher education qualification (Second revision of the Cotonou Agreement signed, Ouagadougou, 22 June 2010, 11329/10 (Presse 187).

239) The treatment of professional services in the EPA, www.crnm.org.

240) Van Criekinge, supra note 179, p. (173) 188.
} 
increasing the brain drain problem and with the EPA containing little flanking measure $^{241}$ guaranteeing a development contribution to the country of origin. Once more the EPA appears to address the desire of the Union and the Member States in attracting highly skilled, but not doing much for the requests of the developing countries for more options regarding lower or unskilled and to ease the minds on the loss of their highly skilled in vulnerable sectors, which could perfectly have been included in the Union/Member State and third country agreement.

\section{Conclusions}

The main aim, as elaborated in the PCD, of making migration work for development, reconciling Europe's desires regarding migration with the development needs of third countries, has mainly worked in the minds of policy makers. Over the years, progress has been made to a more balanced and comprehensive migration policy, but the discourse lingers too much on policy pledges. General policy statements as well as specific legal commitments are showing major lacunas in responding to these demands. Too much emphasis has been put on the security dimension, the interests of the Union and in particular, its Member States. The latter holding on tight to their legal migration competence and showing a lack of political will, resulting not only in a lack of a common approach to migration, but also making the demands of the developing countries too much dependent on their goodwill. These obstacles have left tremendous gaps in a legally coherent migration-development policy guaranteeing the attainment of the MDG.

Where measures have been taken, they are not legally binding and where they are, commitments on the part of the Union are weak, while in parallel imposing strict obligations on the third country. Measures are mainly in the interest of the Union/ Member States and lack an even balance with the needs of the developing country. It is wondered if the change in decision-making to co-decision and qualified majority voting, under Art. 79 TFEU, and to alteration of the CCP to an exclusive competence (Art. 207 TFEU) might offer more leeway for a development friendly evolution in the migration and trade policy. However, recent initiatives, such as the Stockholm programme, the Return Directive, ${ }^{242}$ the apparent evolution of making aid conditional upon cooperation in illegal migration matters and the debate surrounding Article 13 Cotonou, do not seem to

\footnotetext{
241) E.g. the chapter on social aspects contributes to the employment facet of the 7th Partnership with provisions on employment, social policy and decent work.

242) Directive 2008/115/EC of the European parliament and the Council if 16 December 2008 on common standards and procedures in Member States for returning illegally staying third country nationals, OJ L 348/98 of 24 December 2008.
} 
bring a turnabout in this evolution and are in contradiction to the goal of making migration work for development.

It is not suggested that one measure is better than the other, it is however asserted that there is an urgent need for more coherence ${ }^{243}$ between trade, migration and development and for a common approach balancing the interest of both parties, and putting the legal possibilities to their most optimal use.

243) In conformity with Articles 13(1) and 21(3) VEU and Articles 7 TFEU and 208 TFEU. 